\title{
Capital Market Financing, Firm Growth, and Firm Size Distribution
}

\author{
Tatiana Didier ${ }^{a}$ \\ Ross Levine $e^{\text {, c }}$ \\ Sergio L. Schmukler ${ }^{\mathrm{a}, *}$
}

July 18, 2014

\begin{abstract}
Which firms issue equity and debt in domestic and international markets and what happens to their assets, sales, and number of employees? To answer these questions, we assemble a new dataset on firm-level capital raising activity during 1991-2011, which we match with firm attributes for 45,527 listed firms from 51 economies during 2003-2011. We find that only a few of the largest firms issue securities in the median country. Firms issuing bonds are even larger than those issuing equity. Moreover, issuers grow much faster than non-issuers, particularly (a) during the year of issuance, (b) among smaller and younger firms, and (c) in countries with market-based financial systems. Furthermore, the firm size distribution (FSD) of issuers behaves differently from that of nonissuers. Among issuers, smaller firms grow faster than larger ones, tightening their FSD; but among non-issuers, larger firms grow faster than smaller ones, widening their FSD.
\end{abstract}

JEL Classification Codes: F65, G00, G10, G31, G32, L25

Keywords: access to finance, bond markets, capital market development, capital raisings, financial constraints, firm dynamics, firm financing, stock markets

\footnotetext{
${ }^{\mathrm{a}}$ World Bank, ${ }^{\mathrm{b}}$ University of California at Berkeley, ${ }^{\mathrm{c}}$ NBER

* The authors are grateful to Lucas Núñez and Juan Jose Cortina for truly outstanding research assistance. We received very helpful comments from Eugenia Andreasen, Paco Buera, Roberto Fattal-Jaef, and participants at presentations held at the XVII Workshop on International Economics and Finance (San Jose, Costa Rica), the National Institute of Public Finance and Policy (Delhi, India), and the World Bank (Washington, DC). Generous research support came from the World Bank's Development Economics Department, Knowledge for Change Program, and the Latin America and the Caribbean (LAC) Region's Chief Economist Office. This paper is part of the work prepared for the Global Development Finance Report 2015 and the LAC Regional Studies Program of the World Bank. The paper was finished while Schmukler was visiting the Hong Kong Institute for Monetary Research. Email addresses: tdidier@worldbank.org, ross levine@haas.berkeley.edu, sschmukler@worldbank.org.
} 


\section{Introduction}

In this paper, we address two questions related to capital market development and firm financing around the world. First, which firms issue debt and equity in domestic and international markets? Second, what happens to assets, sales, and the number of employees of firms that issue securities relative to non-issuers? Though very basic, these questions have not been answered using a broad cross-section of countries over an extensive period of time. We thus assess these questions by documenting several new patterns concerning capital market financing, firm growth, and the associated evolution of the firm size distribution (FSD). We also discuss how these findings relate and contribute to several strands of research in finance and economics.

To investigate these questions, we assemble a new dataset on firm-level capital market issuance activity during the period from 1991 through 2011, which we match with data on firm attributes for 45,527 listed firms from 51 countries over the period from 2003 to 2011. We then study which firms use securities markets to issue and how they perform during a period of exceptionally rapid capital market development around the world. For instance, between 1991-1995 and 2006-2011 the stock market capitalization as a percentage of gross domestic product (GDP) rose from $35 \%$ to $84 \%$ for the median developed country and from $17 \%$ to $59 \%$ for the median emerging country. Over the same period, the annual amount raised through equity or corporate bond offerings as a percentage of GDP almost doubled for the median country.

We find, first, that for the median country only a small number of large firms issue equity or bonds, and among these issuing firms a small subset receives the majority of funds raised through security issuances. Namely, in the median country, about only 20 listed firms per year issue securities in either their domestic capital market or in an international financial center. Moreover, of these few issuers, the top-5 firms receive over $66 \%$ of the funds raised through bond issuances and over $77 \%$

of the funds raised through equity issuances. We also find that bond issuers are much larger than 
equity issuers. The median listed firm that conducts an equity offering is more than twice as large (as measured by total assets) as the median non-issuing firm. But the median bond-issuing firm is more than thirty-six times as large as the median non-issuing firm. Issuers of equity and bonds are larger than non-issuers at every decile of the FSD; the distribution of issuing firms lies to the right of nonissuing firms.

Second, issuers grow faster than non-issuers in terms of assets, sales, and employment. For example, the median issuer by size experiences asset growth of $12 \%$ per annum, while the median non-issuer grows at 4.5\%. Similar patterns are observed for the average sized issuers and non-issuers and for other deciles of the FSD. Consequently, the FSD of issuing firms moves more to the right over time than that of non-issuing firms. Moreover, issuers experience a significant boost in assets, sales, and employment in the year they sell securities.

Third, the additional average growth of issuers (relative to non-issuers) is not homogeneous along the FSD. The positive growth gap between issuers and non-issuers is particularly pronounced among smaller firms. Although firm age and firm size are correlated and younger firms tend to grow faster than older ones (Cooley and Quadrini, 2001; Albuquerque and Hopenhayn, 2004; Clementi and Hopenhayn, 2006; Haltiwanger et al., 2013), firm age does not fully explain our results. Smaller, issuing firms grow faster than larger, issuing ones across the different age groups.

Fourth, the FSD of issuers and non-issuers behave very differently. Because smaller, issuing firms grow faster than larger, issuing ones, their FSD tightens. But, among non-issuing firms, larger firms grow faster than smaller ones; so they experience a widening of their FSD.

Fifth, the statistics on the median country mask differences across countries. In developed countries with market-based financial systems (measured using the ratio of total banking claims on the private sector to equity market capitalization), firms that issue equity are not necessarily larger than non-issuing firms. Smaller firms issue equity as well. Moreover, the extra growth of issuing 
firms relative to non-issuing ones is larger than in developed countries with bank-based financial systems. In emerging economies, larger equity issuing firms grow faster than smaller equity issuing ones, contrary to the patterns observed in developed countries.

These results contribute to several lines of research. First, corporate finance theory provides predictions on which firms issue securities in general and equity and debt in particular (Harris and Raviv, 1991; Myers, 2003). For example, Dang et al. (2014) argue that firms will use banks less and securities markets more when there are smaller information asymmetries between firms and potential investors. Focusing on debt versus equity, Jensen and Meckling (1976), Myers (1984), Myers and Majluf (1984), and Jensen (1986) indicate that more opaque firms will be more constrained in issuing equity than debt due to the comparatively intensive information asymmetries and transactions costs associated with equity issuances. The pecking order view of corporate finance suggests that more opaque firms will have a greater tendency to tap bond markets before issuing equity (Myers and Majluf, 1984; Fama and French, 2002; Frank and Goyal, 2003, 2008). Researchers often use firm size to proxy for transparency as larger firms tend to be older and more thoroughly researched than smaller firms.

Our finding that larger firms are more likely to issue securities than smaller firms is consistent with the view that firm transparency is positively related to the issuance of securities. However, we also find that, among listed firms, bond issuers tend to be larger than equity issuers. To the extent that firm size is a proxy for transparency, this finding conflicts with the view that opaque listed firms tap bond markets before raising additional funds through equity issuances.

Second, corporate finance theory also provides differing views on why firms issue securities. The textbook explanation is that firms issue securities to fund positive net present value projects. A second, not necessarily contradictory, view is that firms issue securities to change their capital structure. Rather than issuing securities primarily to fund new projects, corporations might do so to 
alter debt-equity ratios, replace expensive financing with cheaper funding, reduce free cash flows, minimize taxes, or change the duration of debt, with corresponding effects on corporate governance, profits, and risk exposure (e.g., Jensen, 1986; Hart, 1995; Graham and Harvey, 2001; Brealey et al., 2011; Shin and Zhao, 2013; Shin, 2014). Because changes in capital structure might be related to corporate investment decisions, it is difficult to distinguish between these two motives for issuing securities.

Our results suggest that the capital structure is not the only factor that changes when firms issue securities. In fact, debt and equity issuances are associated with an immediate and enduring boost in firm size. Issuers grow comparatively rapidly in the year they issue securities and this growth does not simply represent an increase in corporate assets. Sales and the number of employees grow, too. Therefore, the issuance of securities is related to changes in the real side of firms.

Third, as reviewed by Levine (2005), researchers debate whether and how capital markets influence economic growth. Although the size of capital markets and the liquidity of secondary stock markets are positively associated with aggregate growth (Levine and Zervos, 1996, 1998; DemirgucKunt and Maksimovic, 1998; Henry, 2000; Beck and Levine, 2004; Bekaert et al., 2005), researchers have not determined whether the activity in primary markets is associated with growth across a broad cross-section of countries. Namely, is there a direct connection between a firm issuing securities and the growth of its assets, sales, and employment? ${ }^{1}$ Some research suggests that capital markets foster economic growth by lowering the cost of diversifying and pooling risks (Levine, 1992; Obstfeld, 1994; Acemoglu and Zilibotti, 1997). Other research stresses that large, liquid markets increase the expected benefits from researching firms, with positive repercussions on the

\footnotetext{
1 While in this paper we examine the growth of firm assets, sales, and employment around security issuances, the literature has studied why firms issue securities and cross-list and the evolution of capital structure and corporate valuation around these events (Demirguc-Kunt and Maksimovic, 1998; Henderson et al., 2006; Karolyi, 2006; Claessens and Schmukler, 2007; Gozzi et al., 2008, 2010).
} 
creation and dissemination of information (Grossman and Stiglitz, 1980; Holmström and Tirole, 1993). From these perspectives, well-functioning capital markets help listed firms through different channels, not necessarily through new security issuances.

Our findings indicate that when firms choose to issue securities they experience a material boost in assets, sales, and employment relative to listed firms that do not issue securities and relative to their own performance before issuing. This suggests that there is a direct, positive connection between capital raising activity and growth at the firm level. Although issuance is not random and firms might issue when they have growth opportunities, these findings indicate that firms grow faster when they issue, and that it is not just the availability of well-functioning securities markets that fosters the growth of listed firms.

Fourth, a large and rapidly growing literature examines the evolution of the FSD to understand firm dynamics under the presence of financial (and other) frictions. Whereas early papers found support for the Gibrat's law, stating that firm growth is independent of firm size (Simon and Bonnini, 1958; Mansfield, 1962; Ijiri and Simon, 1964), later work found that smaller firms grow faster than larger ones (Evans, 1987). More recently, a growing literature finds for individual countries that (1) smaller and younger firms are more financially constrained, (2) a relaxation of financial constraints has a larger impact on those firms, and (3) the development of financial systems is related to the extent of financial constraints, the evolution of the FSD, and firm dynamics (Cabral and Mata, 2003; Angelini and Generale, 2008; Arellano et al., 2012; Buera et al., 2014; Midrigan and $\mathrm{Xu}, 2014)$.

Our findings relate to this literature. We examine a much wider array of countries than previous studies and focus only on listed firms, which tend to be less financially constrained than non-listed firms and are a more homogeneous group than a sample of all firms. Nevertheless, we find notable heterogeneity even among listed firms. Whereas previous studies find that smaller firms 
grow faster than larger ones, we find that this depends on whether the firms are issuers or nonissuers. Among issuers, smaller firms grow faster, so that their FSD tends to tighten. But among non-issuers, larger firms grow faster than smaller firms, so that their FSD tends to become wider. Our results also emphasize potential connections between financial constraints and the evolution of the FSD. Our finding that small issuing firms grow faster in terms of assets, sales, and employment than larger ones is consistent with the view that financial constraints are especially binding on smaller firms. Moreover, to the extent that issuing securities signals that a firm experiences a relaxation in financial constraints, then our finding that issuing firms enjoy a boost in growth when issuing securities is consistent with the view that financial constraints materially constrain the growth of firms. Furthermore, our finding that the additional growth of issuing firms (vis-à-vis non-issuing ones) is greater in countries with relatively well-developed capital markets than in other economies is consistent with the view that market-based financial systems ease constraints on security issuances, with positive ramifications on the ability of firms to realize their growth opportunities.

Fifth, a large literature emphasizes that capital market development can expand access to finance, loosen financing constraints, and disproportionately boost the growth of small, capable firms (e.g., Demirguc-Kunt and Levine, 2001; Myers, 2003; Stein, 2003; Ayyagari et al., 2013). The findings in this paper provide qualified support for this view. For most countries, only a few large firms issue securities and then grow rapidly. Thus, capital market development around the world has not, in general, involved smaller firms issuing securities to fuel growth. The qualification is that this finding depends on where firms are located. In developed countries with market-based financial systems, it is not just larger listed firms that raise capital through equity offerings. This suggests that, as securities markets across countries develop, the extensive margin among listed firms might expand, so that smaller firms could participate more in these markets.

The remainder of the paper is organized as follows. Section 2 describes the data. Section 3 
briefly describes the evolution of capital market development and how many firms use and capture the capital market activity. Section 4 presents the results on which firms use these markets. Section 5 shows the results on firm performance and the evolution of the FSD. Section 6 explores the heterogeneity in firm behavior according to the type of securities issued, market of issuance, and firms' home market. Section 7 studies the role of firm age. Section 8 concludes.

\section{Data}

To assess which firms issue securities, the comparative performance of issuing and non-issuing firms, and the evolution of the size distribution of firms as they issue securities, we assemble a comprehensive dataset covering firm bond and equity issuances in capital markets around the world as well as balance sheet information on publicly listed firms. The data on firm capital raising activity cover the period 1991-2011 and come from the Thomson Reuters Security Data Corporation (SDC) Platinum database, which provides transaction-level information on new issuances of common and preferred equity and publicly and privately placed bonds with an original maturity of more than one year. ${ }^{2}$ Given that the SDC Platinum database does not collect data on debt issuances with maturities shorter than one year, the dataset does not cover commercial paper. For offerings in more than one market, we consider each market a separate issuance. The dataset includes 532,423 security issuances: 138,968 equity issuances and 393,455 bond issuances. Security issuances are classified as domestic or international based on the location of the main exchange where the issuances take place and compared with the issuing firm's nationality. The dataset includes 411,180 issuances in domestic markets and 116,811 issuances in foreign markets (4,432 issuances are not possible to be classified and have been assigned missing values).

${ }^{2}$ SDC Platinum collects data on security issuance mostly from filings with local regulatory agencies and stock exchanges. These data are augmented with data from other sources such as offering circulars, prospectuses, surveys of investment banks, brokers, and other financial advisors, news sources, trade publications, and wires. 
To examine the comparative characteristic and performance of issuing and non-issuing firms, we match the dataset on security issuances from SDC Platinum with 2003-2011 firm-level balance sheet information from the Orbis (Bureau van Dijk) database. The latter covers publicly listed companies from 155 economies, providing a rather homogeneous sample of firms. By omitting unlisted firms, the sample excludes firms that are (a) relatively small and sometimes informal, (b) likely to have different accounting standards, and (c) less likely to issue in capital markets. Moreover, because of a lack of coverage of capital raising activity in domestic bond markets, Canada and the Republic of Korea are not included in the final sample. Firms from countries with less than 10 issuing firms between 2003 and 2011 are excluded from the final sample and so are the firms from offshore financial centers. The final matched dataset covers 45,527 firms from 51 countries. Overall, our matched dataset covers at least $85 \%$ of the listed firms in each country and 479,501 security issuances. ${ }^{3,4}$

We classify firms as issuers or non-issuers based on whether they issued equity or bonds at any point during our sample period. Because firm-level balance sheet information is only available for the period from 2003 to 2011, we classify a firm as an issuer if it had at least one equity or bond issuance during that period. We further classify whether firms are equity or bond issuers depending on whether firms issued any equity or bonds, respectively. If a firm raised capital through equity and bonds between 2003 and 2011, it is classified both as an equity and as a bond issuer. We also classify firms as domestic or foreign equity issuers and as domestic or foreign bond issuers, depending on whether they issued equity or bonds in domestic or foreign markets. Foreign issuers are the firms that had at least one capital raising issuance in foreign markets between 2003 and 2011. Domestic

\footnotetext{
${ }^{3}$ Appendix Table 1 reports the list of countries and the number of non-issuing and issuing firms from each country covered in the final matched dataset.

4 The number of security issuances in the matched dataset is smaller than that in the SDC Platinum database because several firms that issue securities, especially bonds, do not have balance sheet data in Orbis.
} 
issuers comprise firms that issued only in domestic markets. ${ }^{5}$ Hence, firms that raised capital in both domestic and foreign markets over the sample period are classified as foreign issuers. The sample of non-issuing firms is held fixed throughout the paper. Non-issuing firms are those that did not have any capital raising activity between 2003 and 2011. In the SDC-Orbis data 18,342 firms are issuers (16,198 firms are equity issuers and 5,134 are bond issuers) and 27,185 are non-issuing firms.

We classify the countries in the sample into developed and emerging economies following the World Bank classification of countries. In particular, developed countries are those with a gross national income (GNI) per capita in 2009 above $\$ 12,195$ (U.S. dollars). All other countries are classified as emerging economies. The developed countries are further classified according to their financial structure-whether they have bank- or market-based financial systems. For emerging economies, we do not have enough variation to split this group by bank- and market-based financial systems. However, in additional exercises we classified all countries as bank- or market-based. Following Demirguc-Kunt and Levine (2001) we construct a measure of financial structure based on relative size. The developed countries with an average ratio of total banking claims on the private sector to equity market capitalization above the sample median are classified as bank-based economies, while all the other developed economies are classified as market-based ones. ${ }^{6}$ The final matched dataset comprises firms from 20 emerging countries and 31 developed countries, of which 16 have bank-based financial systems. Appendix Table 1 reports the list of countries in each of these categories.

Our analyses focus on firm size and growth, measured by the level and growth rate of total

\footnotetext{
${ }^{5}$ For robustness, in unreported results, we considered overlapping groups of domestic and foreign issuers. That is, foreign issuers are the firms that had at least one capital raising issuance in foreign markets between 2003 and 2011 , whereas domestic issuers comprise firms that had at least one capital raising issuance in domestic markets over the same period. The results are qualitatively similar to the ones reported in the paper.

6 To classify countries, we use data between 2000 and 2003, but these measures tend to be fairly stable over time. Moreover, several papers show that measures of financial structure based on size are very similar to measures based on activity, such as the ratio of bank credit to value traded in equity markets. Indeed, Beck and Levine (2002) show that the correlations between these two measures are over 0.65 and significant at the 1\% level. Also see Levine (2002), Demirguc-Kunt and Maksimovic (2002), Ergungor (2004), and Demirguc-Kunt et al. (2013).
} 
assets (or assets), sales, and the number of employees. Firm assets and sales are measured in constant 2011 U.S. dollars, using the consumer price index (CPI) to discount nominal values. The analysis also examines firm age (measured in 2011), firm profitability, and other financial indicators such as return on assets (ROA), leverage (including bank and other types of financing), and the maturity profile of liabilities.

We also match the SDC-Orbis dataset with the SDC Platinum database on mergers and acquisitions (M\&A) to assess whether firms with M\&A activity around their capital raisings display a similar performance than other firms raising capital. This helps us analyze whether the patterns we uncover are driven by M\&A activity and whether the expansion of firms comes from their own internal growth. To do so, we identify whether issuing firms engage in some M\&A activity as the acquirer firm in the year of the capital raising or the following year. Of the 18,342 issuing firms in the sample, 8,919 firms conducted an M\&A transaction (about 50\% of the issuing firms). The results using the M\&A data are mentioned in the text but not reported to save space.

Although in this paper we use the firm-level data for 2003-2011 due to the wide coverage of firms by SDC Platinum, we also match the data on security issuances from SDC Platinum with balance sheet information from the Thomson Reuters Worldscope database. One advantage of the matched SDC-Worldscope dataset is that it covers a longer time span, including the 1990s. However, due to the Worldscope coverage, the matched Worldscope dataset contains a smaller set of firms $(38,622$ firms $)$ than the matched Orbis dataset and does not include the United States. A comparison of the sample of firms in Orbis and Worldscope suggests that the Worldscope sample is biased toward larger firms. As for the results using the M\&A data, the results using the Worldscope data are mentioned in the text but not reported. 


\section{Capital Market Growth: The Intensive and Extensive Margins}

Capital markets have grown markedly since the early 1990s in both developed and emerging economies (Figure 1). The median developed country's equity market expanded from an average of $35 \%$ of GDP over the period 1991-1995 to an average of $84 \%$ over 2006-2011. Even more pronounced growth patterns are observed in emerging countries, where markets grew from 17\% to $59 \%$ of GDP over the same period in the median country. Corporate bond markets also grew, especially in emerging economies where they increased more than 6-fold, albeit from a low base. In the median developed country, corporate bond markets expanded from an average of $27 \%$ of GDP in $1991-1995$ to $41 \%$ in $2006-2011$. As a comparison, private credit by deposit money banks increased from $81 \%$ to $117 \%$ (27\% to $36 \%$ ) of GDP in the median developed (emerging) country during the same period.

The expansion in primary capital market activity has also been sizeable (Figure 2, Panel A). For the median country in our sample, the per annum amount of new equity issuances as a proportion of GDP almost doubled, from about 0.7\% during 1991-1995 to $1.3 \%$ during 2006-2011. There has also been pronounced growth in the issuance of corporate bonds, especially in the late 2000s. Bond issuances rose from $1.8 \%$ of GDP per annum for the median country in the early 1990 s to $3.1 \%$ in second half of the 2000 s. Thus, whether considering market size or primary activity, the median country has experienced a noticeable expansion of equity and bond markets.

Capital market growth has been associated mainly with a growth in the intensive margin: a small number of firms have materially increased their use of capital markets since the 1990s. And there has not been much of an increase in the extensive margin, in the number of firms issuing securities. For the median country, the average number of firms issuing equity per year increased from 18 in the early 1990s to 23 in the late 2000s (Figure 2, Panel B). In the case of bonds, the average number of firms per annum issuing them in the median country was 27 in the early 1990s 
and 22 in the late 2000 s. $^{7}$

Not only do few firms raise funds in capital markets, an even smaller number of firms raise the bulk of the financing and account for the rapid growth of security issuances. For example, the amount raised in equity markets per year by the top- 5 issuers in the median country remained at about 80\% of the total amount raised over the entire period 1991-2011 (Figure 2, Panel C). The top5 bond issuers in the median country captured close to $70 \%$ of the total amount raised, with the top20 issuers capturing over $90 \%$.

Although there is cross-country heterogeneity, the patterns described above exist for most economies. Even for the most developed markets, a small proportion of listed firms raise capital through equity or bond issuances (Appendix Figure 1). For example, in France, Germany, the United Kingdom, and the United States less than half of the firms in our sample conducted an equity offering or sold a bond over the period 2003-11. There is also remarkable skewness across virtually all countries. Only in Australia, China, Japan, Hong Kong SAR, the United Kingdom, and the United States is the amount raised by the top- 5 equity issuers less than $50 \%$ of the total amount raised in equity markets. Even in other G7 economies like Germany, France, and Italy, the top-5 equity issuers captured $61 \%, 65 \%$, and $71 \%$ of the total amount raised in our sample period, respectively. The concentration of funds raised by a few large firms in corporate bond markets is also pronounced across most countries.

This concentration in capital market activity does not simply reflect concentration in economic activity. ${ }^{8}$ Within our sample of listed firms, economic activity is indeed concentrated: the top-5 firms in sales capture about $45 \%$ of the total sales (Figure 3, Panel A). However, capital

\footnotetext{
7 If we use a 5-year window, instead of examining issuances per year, the total number of firms issuing equity in the median country increased from 72 in 1991-1995 to 103 in 2006-2011. In the case of bonds, it declined from 87 to 76 firms over the same period.

8 Although Gabaix (2011), di Giovanni and Levchenko (2012), Eaton et al. (2012), and Freund and Pierola (2012) find that the top firms in a country play a crucial role in aggregate outcomes, we find that the concentration in capital market financing does not simply involve the same firms that are concentrated in terms of economic activity.
} 
market activity is concentrated in a different set of firms: the top-5 firms in terms of sales actually capture less than 15\% of the total amount raised in capital markets (Figure 3, Panel B). Consistent with this, the top- 5 issuing firms capture $15 \%$ or less than the total sales by the firms in our sample (Figure 3, Panel C). In other words, although capital markets seem to be a source of financing for relatively few firms, the top issuing firms are not necessarily the top firms in terms of sales.

\section{Which Firms Use Capital Markets?}

To assess which firms access capital markets, we compare the characteristics of non-issuing firms, issuing firms, and the different types of issuing firms. We compare (a) firm size (measured by assets and sales in 2011 U.S. dollars and the number of employees), (b) firm growth (measured by the growth rate of assets, sales, and employees), (c) firm leverage, (d) the liability structure of firm debt (measured by the ratio of long-term debt to total firm liabilities), (e) firm profitability (measured by retained earnings over assets and return on assets, or ROA), and (d) firm age. Besides differentiating by whether firms issue equity or debt, we also examine whether firms issue equity domestically, equity in foreign markets, bonds domestically, or bonds in foreign markets. In comparing firm traits across non-issuing and issuing firms, we use the median across countries of the median firm in any given country, after obtaining the average over time for each firm. Because for the rest of the paper we use the matched dataset on capital raisings and balance sheet information, the sample is restricted to $2003-2011$.

Issuing firms are different from non-issuing firms along many dimensions. Issuers are typically much larger than publicly listed firms that do not issue stocks or bonds (Table 1). The median issuer in the median country (of either equity or bonds) has assets of $\$ 317$ million, while non-issuers have $\$ 100$ million in assets. There are also large size differences across firms that issue equity and bonds and across those that issue securities in domestic and foreign capital markets. The 
median bond issuer has assets of $\$ 3.7$ billion, while the median equity issuer has assets of $\$ 256$ million, which is more than a 14 -fold difference. Moreover, the median firm that issues securities abroad is much larger than the median firm that sells stocks or bonds in domestic markets. The median bond issuer in domestic markets has assets of $\$ 1.5$ billion, whereas the median bond issuer in foreign markets has assets of $\$ 4.9$ billion. The results are qualitatively similar when focusing on either sales or the number of employees rather than assets. ${ }^{9}$

Issuing firms also tend to grow much faster than non-issuing firms (Table 1). While the assets of non-issuing firms grew at a $4.3 \%$ a year during the sample period, the assets of equity and bond issuers grew at $10.5 \%$ and $9.4 \%$ a year, respectively. As a comparison, for the median country (Brazil and Bulgaria), the average GDP growth during this period was 3.9\%. Furthermore, firms that issue equity abroad tend to have faster growth rates than those that issue equity in domestic markets only. The differences in growth rates are also sizeable if we analyze sales and the number of employees. For example, growth in the number of employees for issuers averaged $4.4 \%$ a year, but only $0.9 \%$ for non-issuers between 2003 and 2011.

Do the differences between issuing and non-issuing firms exist before an issuance takes place? Or do they primarily emerge as firms issue equity or bonds? To address this, we estimate Probit models that measure the probability of issuing equity or bonds during the 2005-11 period based on firm-level attributes in 2004 (firms with capital raising activity only in 2003 and/or 2004 are excluded from these regressions). ${ }^{10}$ In each regression, we use only one explanatory variable for

\footnotetext{
9 The median issuing firm tends to be much larger than the median non-issuing firm in virtually all countries. For example, the assets of the median equity-issuing firm are larger than the assets of the median non-issuing firm in all countries except in a handful of cases (Australia, France, Japan, Luxembourg, Malaysia, New Zealand, Singapore, Sweden, Thailand, and the United Kingdom). For about half of the countries, the median equity issuing firm is at least 2.5 times larger than the median non-issuing firm. In the case of bonds, in all but two countries (Australia and Luxembourg) the median bond issuer is at least five times as large as the median non-issuer.

${ }^{10}$ In unreported results, we estimated Cox proportional hazard models to capture the probability of raising capital through equity or bonds. The Cox model estimates the determinants of the probability of issuing equity and bonds by employing all available information up to the year before an issuance takes place. The estimates obtained are consistent with the ones presented using Probit models.
} 
size and one for growth due to multi-collinearity. All the regressions include country dummies to control for country-specific effects. ${ }^{11}$

Many differences between issuers and non-issuers exist before firms issue securities. The results show that larger firms and those with higher growth rates are more likely to raise capital in equity or bond markets (Table 2). Firms with longer-term debt are also more likely to issue. Although issuing firms are ex ante bigger and faster growing, they tend to be less profitable. ${ }^{12}$ With respect to economic significance, firm size is generally the most important predictor of future capital raising activity. For example, a one standard deviation increase in the log of assets for the average firm raises the likelihood of issuing in capital markets by around 18 percentage points. ${ }^{13} \mathrm{~A}$ one standard deviation increase in asset growth is associated with an increase of about 6 percentage points in the probability of issuing a stock or bond. The results using sales or the number of employees as a proxy for size are quantitatively and qualitatively similar. Moreover, a one standard deviation increase in ROA lowers the probability of new capital market activity by about 6 percentage points.

We also estimate the Probit models for the probability of issuing only equity and the probability of issuing only bonds in both domestic and foreign markets. The results are qualitatively similar to the ones obtained by estimating the probability of raising capital in general (Table 2, right panels). The estimations show that firm size, firm growth, and the longer liability maturity structure are positively and statistically related to the use of capital market financing, while firm profitability is

\footnotetext{
${ }^{11}$ In unreported results, we used industry dummies to control for sector-specific effects, following the major industry divisions of the SIC classification at the two-digit level (agriculture, forestry, and fishing; construction; finance, insurance, and real estate; manufacturing; mining; public administration; retail trade; services; transportation, communications, and utilities; and wholesale trade). The results are similar to the ones reported here.

${ }^{12}$ In unreported results, we explored whether changes in profitability occur around the capital raising activity. We find that profitability does not increase in the year following an issuance.

13 The estimates reported in Table 2 show the marginal effects on the probability of issuance of a unit change in each explanatory variable. These variables, however, are in different units, making these effects not directly comparable across variables. Thus, in the text, we discuss the marginal effects associated with a one standard deviation change in the explanatory variables.
} 
negatively associated with issuance activity. The main difference between firms issuing equity and bonds is that the marginal effect of size on the probability of capital raising activity is much higher for bond issuers than for equity issuers. For example, a one standard deviation increase in the $\log$ of assets raises the likelihood of an issuance by about 3 percentage points for equity issuances and by about 30 percentage points for bond issuances.

In sum, as the capitalization of equity and bond markets and the aggregate capital raising activity increased markedly since the 1990s, we find that throughout our sample (i) only a few firms issued securities in the median country, and indeed in the vast majority of countries, (ii) of the few firms that issued securities, only a handful of those accounted for the bulk of the funds raised by listed firms in capital markets, and (iii) the ones that did issue securities in domestic and foreign markets tended to be large and fast growing.

\section{How Do Assets, Sales, and Employment Evolve for Issuing and Non-issuing Firms?}

This section assesses (1) whether issuers grow faster than non-issuers, (2) whether a bump in growth materializes immediately after a firm issues securities, and (3) how the growth gap between issuers and non-issuers differs across the full distribution of firm size.

We begin by estimating four probability density functions that capture the FSD: two for 2003 (one for issuers of either equity or bonds and one for non-issuers) and two analogous ones for 2010. Due to data availability on firm-level balance sheets in Orbis, we focus the rest of the paper on the 2003-2010 sample. That is, issuing firms that raised capital through equity or bonds only in 2011 are excluded from the analysis henceforth. However, the results are qualitatively similar if we use the full sample available for 2003-2011.

As illustrated in Figure 4, three key findings emerge about the FSD when using assets, sales, or the number of employees to measure firm size. First, the distribution of issuers in 2003 is to the 
right of that of non-issuers, indicating that issuing firms are typically larger ex ante than non-issuing firms. These patterns are consistent with the evidence presented in the previous section that larger firms are more likely to issue equity and debt securities. Second, the FSD for both issuing and nonissuing firms shifted to the right from 2003 to 2010, indicating that publicly listed firms typically grew over this period. Third, the distribution of issuing firms shifted farther to the right than that of non-issuers, implying that issuing firms grew more than non-issuing ones while they issued securities. The differences in the FSD are statistically significant based on unreported KolmogorovSmirnov statistics.

To further assess whether issuing firms are typically larger and faster growing than nonissuing ones across the distribution of firm sizes, we estimate quantile regressions using differencesin-differences specifications. More specifically, we use information on firm size for 2003 and 2010 for all firms in the sample, and estimate quantile regressions on a constant, a dummy for issuer firms, a 2010 dummy variable that takes the value of one for observations in 2010, and a term interacting these two dummy variables. We estimate these regressions using the log of assets, sales, or the number of employees as dependent variables.

The estimated coefficients from the quantile regressions in Table 3 are reported in exponential form and need to be interpreted as follows. For a given quantile, the constant term measures the size in 2003 of non-issuing firms. The coefficient on the dummy for whether it is an issuing firm measures the size of issuers relative to the size of non-issuers in 2003. The coefficient on the 2010 dummy measures the growth rate of non-issuing firms between 2003 and $2010 .{ }^{14}$ The coefficient on the interaction term (the interaction between the dummy for an issuing firm and the dummy for observations in 2010) measures the growth of issuers relative to non-issuers; therefore, it

\footnotetext{
${ }^{14}$ The level of the $j^{\text {th }}$ quantile of size for non-issuing firms in 2010 can be obtained by multiplying the constant and the reported coefficient on the 2010 dummy variable. Similar calculations make it possible to recover the levels of the $j^{\text {th }}$ quantiles for the other distributions.
} 
captures whether the distribution of issuers shifts more to the right than that of non-issuers between 2003 and 2010. Thus, the coefficient on this interaction term is of special interest.

Consistent with the kernel density estimates, the results of the quantile regressions show that issuing firms are ex ante larger than non-issuing firms. Importantly, not only are the top firms in the distribution of issuers larger than the top firms in the distribution of non-issuers, but these differences also exist at every decile of the distributions, including the bottom ones. That is, the entire distribution of issuing firms lies to the right of that of non-issuing firms. The results are statistically significant for all estimates, except for the bottom deciles of the distribution of the number of employees. These differences are also economically significant. For example, issuing firms at the $1^{\text {st }}$ decile are larger than non-issuing firms at the same decile of the distribution by $63 \%$ in assets, $24 \%$ in sales, and $7 \%$ in the number of employees.

Issuing firms not only start larger than non-issuing firms, but they also grow much faster than non-issuing firms at all deciles of the distribution. In other words, there is actually ex post divergence in firm size between issuers and non-issuers. The coefficients on the interacted term are larger than one and statistically significant for every estimated decile, with the exception of the top decile of the FSD in all three specifications (assets, sales, and the number of employees), thus providing evidence that issuing firms grew faster than non-issuing firms over the same period. There is in fact a sizeable additional shift in the distribution of issuing firms vis-à-vis that of non-issuing firms between 2003 and 2010, after taking into account the initial differences in size between issuers and non-issuers. For example, as shown by the estimated interacted term, the ratio of firm size between issuers and non-issuers at the bottom $1^{\text {st }}$ decile of the distribution of assets increased $115 \%$ over this period; issuing firms were 63\% larger than non-issuing firms in 2003 and became 250\% larger by 2010. The implied differential in annualized growth rates is substantial. Non-issuing firms at the $1^{\text {st }}$ decile of the distribution of assets grew 1.6\% per year between 2003 and 2010, whereas 
issuing firms at the same decile of the distribution grew $13.3 \%$ per year over the same period. Qualitatively similar differences are estimated for sales and the number of employees.

Figure 5 plots the growth rate of issuers and non-issuers implied by the regressions for the different deciles of the distribution of assets, sales, and the number of employees. Table 4 shows the inter-quantile tests of equality of coefficients and compares the $5^{\text {th }}$ decile with the $1^{\text {st }}$ decile, the $6^{\text {th }}$ with the $2^{\text {nd }}$, and so forth. These tests not only provide quantitative evidence on the statistical differences across deciles, but also capture the monotonicity of these effects.

For non-issuing firms, there is divergence in the distribution of firm size. The estimated coefficients on the 2010 dummy variable in Table 3 are larger for higher deciles than for the lower ones. While one observes growth for all deciles of non-issuing firms, we find faster growth among the larger non-issuing firms. For example, firms at the $1^{\text {st }}$ decile of the distribution of assets grew 1.6\% per year between 2003 and 2010, whereas firms at the $9^{\text {th }}$ decile of the distribution grew $6.4 \%$ per year. The increase in growth rates is more subdued for the distributions based on sales and the number of employees.

In contrast, there is convergence in the distribution of firm size among issuing firms. That is, smaller firms typically grow faster than larger firms. Moreover, the growth rates of issuing firms actually decrease monotonically with firm size as indicated by the negative inter-decile tests in Table 4. The decline in growth rates is particularly accentuated in the top half of the FSD, with tests between the $9^{\text {th }}$ and the $5^{\text {th }}$ deciles statistically significant for all three distributions. These differences in growth rates are in fact quantitatively large. For instance, issuing firms at the $9^{\text {th }}$ decile typically grew around $52 \%$ less than issuing firms at the $5^{\text {th }}$ decile of the distribution of assets between 2003 and 2010 .

These growth patterns imply that the growth differential between issuing and non-issuing firms is much greater for smaller firms than for larger firms (Figure 5). Namely, issuing firms grow 
faster than non-issuing firms at each decile of the distribution of firm size, but the growth gap between small issuing and non-issuing firms is much larger than the growth gap between large issuing and non-issuing firms. The negative and statistically significant inter-decile tests (Table 4) show that this growth differential for issuers relative to non-issuers declines monotonically with firm size. In fact, as indicated by the interacted coefficients (Table 3), at the $9^{\text {th }}$ decile the differences in growth rates between issuing and non-issuing firms are no longer statistically significant.

The previous estimations of the FSD do not distinguish firms by country (they pool all the observations) because for most countries very few firms issue securities and the FSD cannot be estimated at the country level. But to assess whether the patterns we find are driven by countryspecific effects (in particular, by countries growing at different rates), we estimate cross-sectional regressions of total firm growth between 2003 and 2010 on country fixed effects and a dummy variable that captures whether the firm is an issuer (Table 5). Analogous to the estimations in Table 3, we split firms into deciles according to their size in 2003 and estimate standard linear regressions using observations within each decile. The results are consistent with the findings in Table 3. Issuing firms grew faster between 2003 and 2010 than non-issuing firms. Moreover, the estimated coefficients for the issuing dummy are typically larger at the lower deciles than the upper deciles, indicating convergence in size within issuing firms over time.

We next assess whether growth rises at the time of issuance. Because the estimations in Tables 3 and 5 show results for the entire 2003-2010 period, they do not show what happens in the year when firms actually issue. To do so, we first conduct an event study, computing the growth rate of issuers versus non-issuers in each year (+/- 3 years) around the time of issuance, grouping firms by their year of first issuance. The results show that while issuers grow faster than non-issuers before and after they issue, the growth rate at the time of issuance increases significantly (Figure 6).

We then pool the groups of firms issuing in different years and estimate panel regressions. 
On average, the assets of issuing firms continuously rise over the 7-year window around a capital raising issue (Table 6, Panel A). Moreover, the average asset growth of issuers is higher than that of non-issuers, particularly so during the year of issuance: 8.6 percentage points one year before issuing, 22.7 percentage points the year of issuance, and 8.2 percentage points the year after issuance (Table 6, Panel B). This differential growth becomes smaller two and three years before and after issuing. Similar patterns are obtained when using sales and the number of employees.

These estimates provide additional evidence on two key features of security issuances. First, it is not just that fast growing firms are more likely to issue securities. Rather, firm assets, sales, and employment tend to rise substantially in the year they issue securities. Second, firms do not issue securities simply to adjust their capital structure. Instead, the estimates in levels and growth rates show that assets, sales, and employment rise as firms issue securities.

We conducted a number of additional robustness tests. First, the results presented in this paper are quantitatively and qualitatively robust to the exclusion of financial and utility firms. Moreover, the results hold when using only financial and utility firms, suggesting that they do not behave differently than firms in other industries. Second, the results hold when controlling for M\&A activity. In particular, the results are robust to the exclusion of firms that engage (as acquirer) in an M\&A activity in the year of the capital raising or in the following year. Third, Chinese and Indian firms represent a relatively large fraction of the sample (about 16\%) and the patterns documented in this paper are similar in these two countries (Didier and Schmukler, 2013). However, the results are qualitatively similar to the ones reported here when excluding China and India, which indicates that these countries are not driving the results. Fourth, the results are robust when considering only the second half of the sample, namely 2006-2010. Fifth, the results are also qualitatively similar to the ones reported here when using the Worldscope balance sheet database that covers a longer time span (1995-2011). In particular, we estimated the regressions over three different sample periods 
(1995-2011, 1995-2002, and 2003-2011) to verify the robustness of our findings to these different partitions. Sixth, although the analysis considers both IPO (initial public offerings) and non-IPO capital raising activity, the results are robust to the exclusion of IPO capital raising activity. Seventh, the reported estimates from quantile regressions use bootstrapped standard errors with 400 replications clustered at the firm level. The results are robust to the alternative use of more replications, non-clustered standard errors, and other levels of clustering (country, sector, and country-sector level).

Overall, firms that use capital market financing are larger to begin with, grow faster, especially in the year of issuance, and become larger than non-issuing firms. There is not only divergence in size between issuing and non-issuing, but also within non-issuing firms, as the growth rates of non-issuing firms increase with firm size. However, within issuing firms the growth rates decrease monotonically with firm size, indicating convergence in size among them. Furthermore, the growth differential between issuing and non-issuing firms is significantly larger for smaller firms.

\section{Heterogeneity in Firm Behavior}

To provide additional information on the characteristics and performance of issuing firms, we split these firms by (1) type of securities issued (equity versus bonds), (2) issuing market (domestic versus foreign), and (3) the level of financial development of the firms' home market (bank-based developed countries, market-based developed countries, and emerging countries). In additional tests, we compared developed versus emerging countries and bank-based versus market-based countries (pooling developed and emerging countries) and obtained qualitatively similar conclusions. We do not report those results to reduce the number of tables. For the same reason we provide results based only on assets, but the findings are robust to using sales or the number of employees.

For the split between equity and bond financing, we define equity issuers as those firms that 
raised capital through equity securities between 2003 and 2010. The issuing firms that raised capital through just bonds (not equity) between 2003 and 2010 are excluded from this sample. We use an analogous definition for bond issuers. As in the previous section, the issuing firms with capital raising activity only in 2011 are also excluded from the sample. The control group of non-issuing firms is the same in both cases and it is the same as in the previous section, namely, the firms that did not issue either equity or bonds over the sample period.

The results show that bond issuers are much larger than equity issuers at all deciles of the FSD (Table 7, Panels A and B). For example, equity issuers at the $1^{\text {st }}$ decile of the distribution were $17 \%$ larger than non-issuers in 2003, whereas bond issuers were 1,391\% larger. Moreover, equityissuing firms grew relatively faster than bond issuing firms between 2003 and 2010. For example, after taking into account the initial differences in size between issuers and non-issuers, equity issuers at the $5^{\text {th }}$ decile of the distribution grew $73 \%$ more than non-issuers, whereas bond issuers at the same decile of the FSD had an expansion in assets of $41 \%$ more than non-issuers. These differences are statistically significant according to unreported tests. In sum, firms that issue equity are smaller than bond issuers and tend to experience faster growth than bond issuers.

To assess whether there are differences between domestic and foreign capital raising activity, we define foreign issuers are the firms that had at least one capital raising issue in foreign markets between 2003 and 2010. Domestic issuers comprise firms that issued only in domestic markets. The control group consists of those firms that did not issue equity or bonds in domestic or foreign markets over the sample period. The results reported here are quantitatively and qualitatively robust to separately analyzing the patterns for domestic equity issuers, foreign equity issuers, domestic bond issuers, and foreign bond issuers.

The core findings that issuers are larger and grow faster than non-issuers hold across markets (Table 7, Panels C and D). Firms that use domestic capital market financing, be it equity or 
bond financing, start out larger and grow faster than non-issuing firms. For instance, the median firm issuing domestically is twice as large as non-issuers. In contrast, the median firm issuing abroad is 26 times as large. Despite being considerably larger, firms issuing in foreign markets also typically grow faster than non-issuing firms. Complementing and reinforcing the previous results, the differential growth of issuers in foreign markets relative to non-issuers also declines monotonically with firm size. At the $9^{\text {th }}$ decile, the differences in growth between both equity and bond foreign issuers and non-issuers are typically no longer statistically significant. Small, foreign issuers grow faster than small, domestic issuers.

Next, we examine the characteristics and performance of issuing firms by differentiating the nature of their home securities markets. Tables 8 and 9 show quantile regressions for equity and bond issuers for developed and emerging countries separately, the former are also split according to whether they have bank-based or market-based financial systems.

In terms of ex ante firm size, equity issuers at the bottom half of the distribution in marketbased developed economies are significantly smaller than non-issuing firms, contrary to the trends observed in developed bank-based economies. For example, equity-issuing firms at the $1^{\text {st }}$ decile of the distribution in developed bank-based economies are four times larger than non-issuing firms at the same decile, while in developed market-based economies equity issuers are $52 \%$ smaller than non-issuing firms.

There are also some differences in the growth patterns for issuing firms across countries. In particular, the magnitude of the growth differentials between issuing and non-issuing firms in market-based developed countries is consistently larger than in developed bank-based economies for firms of different sizes, especially those at the bottom deciles. In emerging countries, both nonissuing firms and equity-issuing firms at the top deciles of the distribution typically grow faster than those at the bottom deciles. These patterns imply a divergence in the FSD for both equity-issuing 
and non-issuing firms. Furthermore, the growth differential between equity-issuing and non-issuing firms is somewhat stable across the different deciles. In the case of bonds, the growth differential between issuing and non-issuing firms declines with firm size.

To summarize, there is heterogeneity in firm size and performance around capital raising activity depending on whether the securities are equity or debt, whether they are issued in domestic or foreign markets, and whether the firm's home market is emerging, or a more bank-based or market-based financial system. First, firms that issue equity are smaller than bond issuers and tend to experience faster growth than bond issuers. Second, firms that issue securities in foreign markets are typically much larger than domestic issuers, and small, foreign issuers tend to grow faster than small, domestic issuers. Thus, firm attributes and performance vary with the location of issuance. Third, equity issuers at the bottom half of the distribution of firm size in market-based developed economies are significantly smaller than non-issuing firms, which is the opposite of the patterns observed in developed bank-based economies. Among listed firms, being large is not a defining characteristic of equity-issuing corporations in developed economies with highly developed stock markets. Fourth, the growth differential between issuers and non-issuers in developed market-based economies is consistently larger than the growth gap in developed bank-based countries. And in emerging economies larger equity issuing firms grow faster than smaller issuing firms, contrary to the patterns observed in developed countries.

\section{The Role of Firm Age}

The results presented above suggest that (1) firms that issue securities tend to be larger than those that do not, (2) issuers tend to grow faster than non-issuers, and (3) smaller issuing firms grow faster than larger issuing firms, indicating that the FSD of issuing firms tends to converge over time. In this section we assess whether these results simply reflect firm age, because size, age, and the degree 
to which firms issue securities are correlated and because the median issuing firm (in the median country) is typically younger than the median non-issuing firm (Table 1).

We explore the degree to which firm age accounts for our results in two ways. To capture its average effect, we first estimate panel regressions of firm size in 2003 and 2010 and cross-sectional regressions of firm growth between 2003 and 2010, both on age and issuance activity as explanatory variables. Second, we assess whether the evolution of the FSD for issuing and non-issuing firms differs across three firm age groups: young firms (10 years or younger in 2011), mature firms (11-30 years in 2011), and old firms (older than 30 years in 2011). ${ }^{15}$

After controlling for firm age, Table 10 indicates that our core results hold: issuing firms start out larger and grow faster than non-issuing firms. Moreover, the results in Panels A and B for the three proxies for firm size (assets, sales, and the number of employees) are quantitatively similar to those reported in the last columns of Tables 3 and 5, respectively. These patterns hold on average for both equity and bond issuers in bank-based and market-based developed countries and in emerging economies.

Our findings regarding the FSD are qualitatively robust to the split of the sample by firm age (Table 11). The estimated coefficients on the issuer dummy show that issuing firms are ex ante larger than non-issuing firms for firms in all age groups. The results are statistically significant for all estimates across all deciles. Issuing firms are not only larger to start with, but they also grow faster than non-issuing firms across the three age groups. Also consistent with our previous findings, the regressions show as well that while non-issuing firms of all ages expanded between 2003 and 2010, their growth rates increased with firm size, especially for young and mature firms. In contrast, within

\footnotetext{
15 The results are robust to the use of other thresholds on firm age. In particular, we obtained qualitatively similar results with the following splits: (i) based on the deciles of the firm age distribution (17 years and younger, 18-32 years, more than 32 years in 2011); (ii) balanced split of firms into three groups (18 years and younger, 19-40 years, more than 40 years in 2011); (iii) 15 years and younger, 16-25 years, more than 25 years in 2011; (iv) 10 years and younger, 11-20 years, more than 20 years in 2011 .
} 
issuing firms, smaller firms typically grew faster than larger firms. Hence, these results indicate that there is some divergence in the distributions of firm size for non-issuing firms and convergence for issuing firms. These patterns are observed for young, mature, and old firms.

In addition, the growth differential between issuing and non-issuing firms declines with firm age. The growth differential for younger firms is larger than that for mature firms, which in turn is larger than that for old firms. For example, the growth differential between issuing and non-issuing firms in the $1^{\text {st }}$ decile of the distribution of young firms is 36 percentage points per year between 2003 and 2010, whereas the differential in the same decile of the distribution of mature and old firms is 10 and 4 percentage points per year, respectively. The estimations show that, controlling for firm size, firm age and growth are negatively associated, especially for issuing firms, as younger firms typically expanded faster than older ones between 2003 and 2010.

Overall, our results show that even after controlling for age, firms that use capital market financing are larger to begin with and grow faster than non-issuing firms. There is not only divergence in size between issuing and non-issuing, but also within non-issuing firms across firms in the three age groups. Within issuing firms the growth rates decrease with firm size. Furthermore, the growth differential between issuing and non-issuing firms is significantly larger for smaller firms across firms of all age groups. These patterns suggest that smaller firms (after controlling for age) and younger firms (after controlling for size) tend to grow faster after issuing securities than larger and older firms.

\section{Conclusions}

During the boom in capital market activity around the world that started in the 1990s, which firms accessed those markets and how did they perform? Using a new dataset on firm-level capital raising activity and balance sheet information, this paper shows that relatively few firms use equity and 
bond markets to obtain financing. The data on capital raising activity show that, for the median country, only around 20 firms per country per year issue equity or bonds, and not many firms do so even in developed countries. Moreover, the capital raising activity is concentrated in large, fastgrowing firms, with the top-5 issuers capturing 66\%-93\% of the activity. In particular, the assets of issuing firms grew on average at 12\% per year between 2003 and 2010, while those of non-issuers grew at $4 \%$ per year. During the year of issuance, firms tend to grow at a much more rapid rate relative to other years, and relative to non-issuing firms. As a consequence of the faster growth, the FSD of issuing firms shifts to the right of the FSD of non-issuing firms (issuing firms become larger). While there is divergence between issuing and non-issuing firms, there is convergence within issuing firms because smaller firms grow faster than larger ones. Among non-issuing firms, however, there is divergence as growth rates increase with firm size.

The findings in this paper indicate that the expansion of primary market activity is much less widespread than some might infer from, for example, simply observing the large increases in market capitalization around the world. Capital markets have not been a significant source of financing for the majority of listed firms. The few, large firms that typically issue equity and bonds across most economies tend to grow faster than non-issuers. And among issuing firms, the smaller firms are the ones that experience the largest boost in growth.

There are some notable differences across countries depending on the degree of economic and capital market development. Whereas in most countries issuing firms are larger than non-issuing firms, in market-based developed economies relatively smaller firms also issue equity. Moreover, the growth differential between issuers and non-issuers is systematically larger across all firm sizes in market-based developed economies than in other developed countries. This is consistent with the view that the benefits of using capital markets are greater in countries where capital markets play a larger role and that better developed markets are associated with a wider array of firms accessing and 
benefitting from the services provided by those markets.

The findings in this paper shed new light on debates concerning the mechanisms through which capital markets influence firm growth. We find a strong, positive association between firms issuing securities and firm growth. It is not just that firms grow faster in economies with better functioning capital markets. Rather, we find that within an economy, issuers (especially smaller ones) grow much faster than non-issuers. This evidence does not reject theories that predict that firms do not need to sell securities to reap the benefits of better capital markets, but it does establish that there is a strong positive relation between issuance and firm growth across a wide array of economies. Future research needs to identify the degree to which supply side factors (such as improvements in capital markets that relax financing constraints) drive the positive association between capital raising and firm growth.

The findings in this paper also suggest that capital market financing is not just associated with changes in corporate capital structure. Assets, sales, and the number of employees expand as firms sell equity or bonds, so firms are not merely using the issuance of securities to alter debt-equity ratios or to replace internal financing or bank lending. Moreover, the fact that firms expand not only in terms of assets but also in terms of sales and the number of employees suggests that their growth is not just related to a balance sheet expansion. 


\section{References}

Acemoglu, D., Zilibotti, F., 1997. Was Prometheus unbound by chance? Risk, diversification, and growth. Journal of Political Economy 105(4), 709-51.

Albuquerque, R., Hopenhayn, H.A., 2004. Optimal lending contracts and firm dynamics. Review of Economic Studies 71(2), 285-315.

Angelini, P., Generale, A., 2008. On the evolution of firm size distributions. American Economic Review 98(1), 426-438.

Arellano, C., Bai, Y., Zhang, J., 2012. Firm dynamics and financial development. Journal of Monetary Economics 59(6), 533-549.

Ayyagari, M. Demirguc-Kunt, A., Maksimovic, M., 2013. Financing in developing countries. In Handbook of the Economics of Finance. Vol. 2A, G. Constantinides, M. Harris, and R. Stulz (eds.), 683-757. Amsterdam: Elsevier.

Beck, T., Levine, R., 2002. Industry growth and capital allocation: does having a market- or bankbased system matter? Journal of Financial Economics 64(2), 147-180.

Beck, T., Levine, R., 2004. Stock markets, banks, and growth: panel evidence. Journal of Banking and Finance 28(3), 423-442.

Bekaert, G., Harvey, C.R., Lundblad, C., 2005. Does financial liberalization spur economic growth. Journal of Financial Economics 77(1), 3-55.

Brealey, R., Myers, S., Allen, F., 2011. Principles of Corporate Finance, Global Edition. New York: McGraw-Hill/Irwin.

Buera, F., Fattal-Jaef, R., Shin, Y., 2014. Anatomy of a credit crunch: from capital to labor markets. UCLA and Washington University, mimeo.

Cabral, L., Mata, J., 2003. On the evolution of the firm size distribution: facts and theory. American Economic Review 93(4), 1075-1090.

Claessens, S., Schmukler, S., 2007. International financial integration through equity markets: which firms from which countries go global? Journal of International Money and Finance 26(5), 788-813.

Clementi, G.L., Hopenhayn H.A., 2006. A theory of financing constraints and firm dynamics. Quarterly Journal of Economics 121(1), 229-265.

Cooley, T., Quadrini, V., 2001. Financial markets and firm dynamics. American Economic Review 91(5), 1286-1310.

Dang, T., Gorton, G., Holmström, B., Ordoñez, G., 2014. Banks as secret keepers. Columbia, Yale, MIT, and University of Pennsylvania, mimeo.

Demirguc-Kunt, A., Feyen, E., Levine, R., 2013. The evolving importance of banks and securities markets. World Bank Economic Review 27(3), 476-490.

Demirguc-Kunt, A., Levine, R. (eds.), 2001. Financial Structure and Economic Growth: A Crosscountry Comparison of Banks, Markets, and Development. Cambridge, MA: MIT Press.

Demirguc-Kunt, A., Maksimovic, V., 1998. Law, finance, and firm growth. Journal of Finance 53(6), 2107-2137.

Demirguc-Kunt, A., Maksimovic, V., 2002. Funding growth in bank-based and market-based financial systems: evidence from firm-level data. Journal of Financial Economics 65(3), 337-363. 
Didier, T., Schmukler, S., 2013. The financing and growth of firms in China and India: evidence from capital markets. Journal of International Money and Finance 39(c), 111-137.

di Giovanni, J., Levchenko, A., 2012. Country size, international trade, and aggregate fluctuations in granular economies. Journal of Political Economy 120(6), 1083-1132.

Eaton, J., Kortum, S., Sotelo, S., 2012. International trade: linking micro and macro. NBER Working Paper No. 17864.

Ergungor, O.E., 2004. Market- versus bank-based financial systems: do rights and regulations really matter? Journal of Banking and Finance 28(12), 2869-2887.

Evans, D.S., 1987. The relationship between firm growth, size, and age: estimates for 100 manufacturing industries. Journal of Industrial Economics 35(4), 567-81.

Fama, E., French, K.R., 2002. Testing trade-off and pecking order predictions about dividends and debt. Review of Financial Studies 15(1), 1-33.

Frank, M.Z., Goyal, V.K., 2003. Testing the pecking order theory of capital structure. Journal of Financial Economics 67(2), 217-248.

Frank, M.Z., Goyal, V.K., 2008. Trade-off and pecking order theories of debt. In Handbook of Corporate Finance: Empirical Corporate Finance. Vol. 2, E. Eckbo (ed.), 135-202. Amsterdam: Elsevier.

Freund, C., Pierola, M.D., 2012. Export superstars. World Bank Policy Research Working Paper No. 6222.

Gabaix, X., 2011. The granular origins of aggregate fluctuations. Econometrica 79(3), 733-772.

Gibrat, R., 1931, Les Inegalites Economiques. Paris: Librairie du Recueil Sirey.

Gozzi, J.C., Levine, R., Schmukler, S., 2008. Internationalization and the evolution of corporate valuation. Journal of Financial Economics 88(3), 607-632.

Gozzi, J.C., Levine, R., Schmukler, S., 2010. Patterns of international capital raisings. Journal of International Economics 80(1), 45-57.

Graham, J., Harvey, C., 2001. The theory and practice of corporate finance: Evidence from the field. Journal of Financial Economics 60(2), 187-243.

Grossman, S.J., Stiglitz, J.E., 1980. Stockholder unanimity in making production and financial decisions. Quarterly Journal of Economics 94(3), 543-66.

Haltiwanger, J., Jarmin, R., Miranda, J., 2013. Who creates jobs? Small versus large versus young. Review of Economics and Statistics 95(2), 347-361.

Harris, M., Raviv, A., 1991. The theory of capital structure. Journal of Finance 46(1), 297-355.

Hart, O., 1995. Firms Contracts and Financial Structure. New York: Oxford University Press.

Henderson, B.J., Jegadeesh, N., Weisbach, M.S., 2006. World markets for raising new capital. Journal of Financial Economics 82(1), 63-101.

Henry, P.B., 2000. Stock market liberalization, economic reform, and emerging market equity prices. Journal of Finance 55(2), 529-564.

Holmström, B., Tirole, J., 1993. Market liquidity and performance monitoring. Journal of Political Economy 101(4), 678-709.

Ijiri, Y., Simon, H.A., 1964. Business firm growth and size. American Economic Review 54(2), 7789. 
Jensen, M.C., 1986. Agency costs of free cash flow, corporate finance and takeovers. American Economic Review 26(1) 323-329.

Jensen, M.C., Meckling, W.H., 1976. Theory of the firm: managerial behavior, agency costs and ownership structure. Journal of Financial Economics 3(4), 305-360.

Karolyi, A., 2006. The world of cross-listings and cross-listings of the world: challenging conventional wisdom. Review of Finance 10(1), 99-152.

Levine, R., 1992. Financial structures and economic development. World Bank Policy Research Working Paper Series No. 849.

Levine, R., 2002. Bank-based or market-based financial systems: which is better? Journal of Financial Intermediation 11(4), 398-428.

Levine, R., 2005. Finance and growth: theory and evidence. In Handbook of Economic Growth. Vol. 1A, P. Aghion and S. Durlauf (eds.), 865-934. Amsterdam: Elsevier.

Levine, R., Zervos, S., 1996. Stock market development and long-run growth. World Bank Economic Review 10(2), 323-39.

Levine, R., Zervos, S., 1998. Stock markets, banks, and economic growth. American Economic Review 88(3), 559-586.

Mansfield, E., 1962. Entry, Gibrat's law, innovation, and the growth of firms. American Economic Review 52(5), 1023-1051.

Midrigan, V., Xu, D., 2014. Finance and misallocation: evidence from plant-level data. American Economic Review 104(2), 422-58.

Mitton, T., 2008. Institutions and concentration. Journal of Development Economics 86(2), 367394.

Myers, S.C., 1984. The capital structure puzzle. Journal of Finance 39(3), 575-592.

Myers, S.C., 2003. Financing of corporations. In Handbook of the Economics of Finance. Vol. 1A, G. Constantinides, M. Harris, and R. Stulz (eds.), 215-253. Amsterdam: Elsevier.

Myers, S.C., Majluf, N.S., 1984. Corporate financing and investment decisions when firms have information that investors do not have. Journal of Financial Economics 13(2), 187-221.

Obstfeld, M., 1994. Risk-taking, global diversification, and growth. American Economic Review 84(5), 1310-1329.

Simon, H.A., Bonini, C.P., 1958. The size distribution of business firms. American Economic Review 48(4), 607-617.

Shin, H.S., 2014. Complexity and funding stability. Presentation at the OFR-FSOC Third Annual Conference.

Shin, H.S., Zhao, L.Y., 2013. Firms as surrogate intermediaries: evidence from emerging economies. Princeton University, mimeo.

Stein, J.C., 2003. Agency, information, and corporate investment. In Handbook the Economics of Finance. Vol. 1A, G. Constantinides, M. Harris, and R. Stulz (eds.), 111-165. Amsterdam: Elsevier. 


\section{FIGURE 1. SIZE OF FINANCIAL SYSTEMS}

This figure shows claims on the private sector (credit) by deposit money banks (and other financial institutions), domestic equity market capitalization, and private bond market capitalization as a percentage of GDP between 1991 and 2011. The measures for each type of financial market are calculated as the median across countries of the average across years for each country. The data source is the Financial Development and Structure database of the World Bank.

\section{A. Developed Economies}

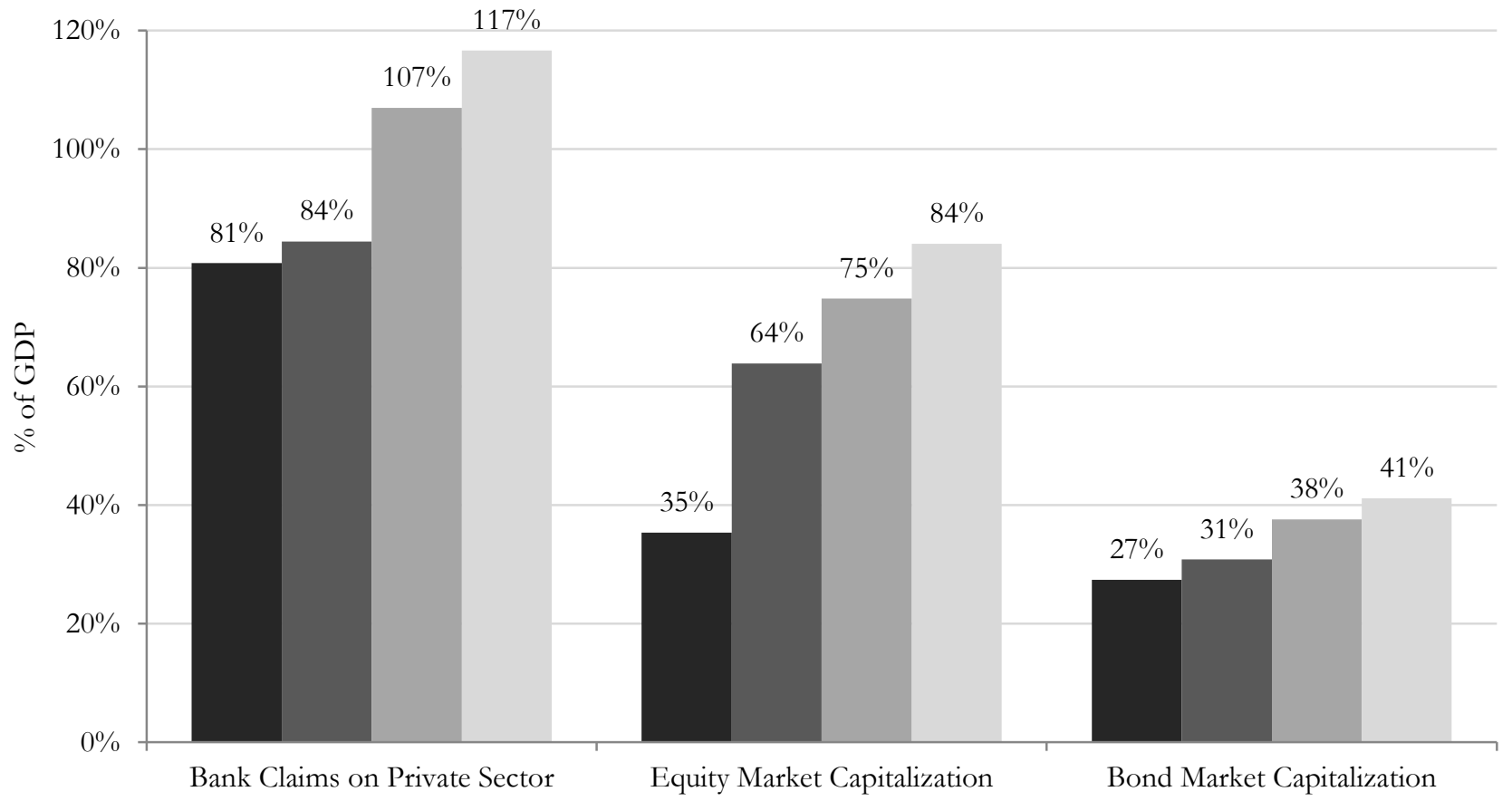

\section{B. Emerging Economies}

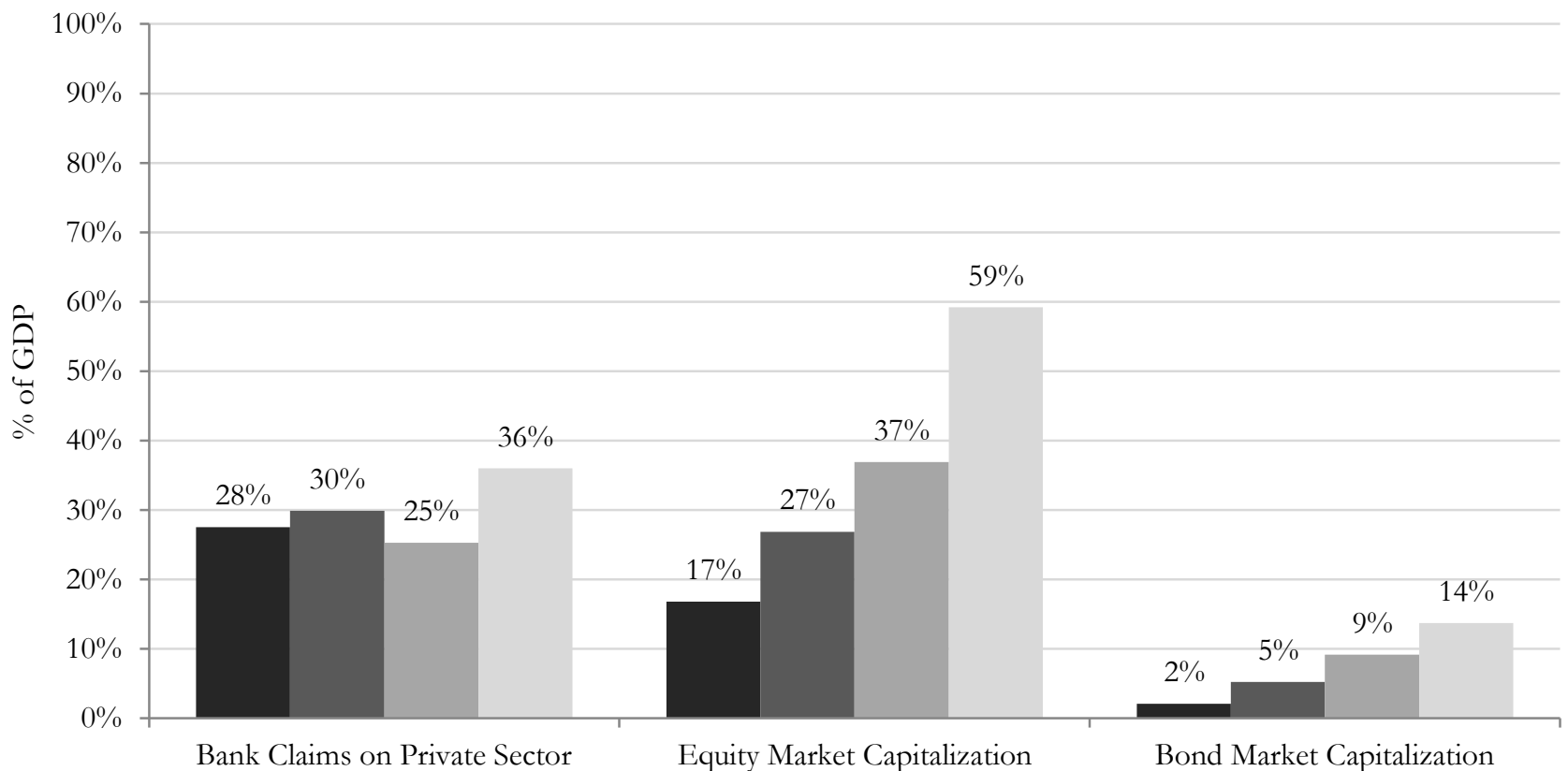

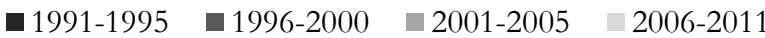




\section{FIGURE 2. ISSUANCE ACTIVITY}

This figure shows in panel A the median amount raised in equity and bond markets as a percentage of GDP. Panel B shows the median number of issuing firms per year in equity and bond markets. Panel $\mathrm{C}$ shows the median amount raised by the top-5, top-

10 , and top- 20 issuers as a percentage of the total amount raised. All the measures are calculated as the median across countries of the average across years by country. The data on bonds for China and India are available only for the period 2000-2011.

\section{A. Amount Raised}

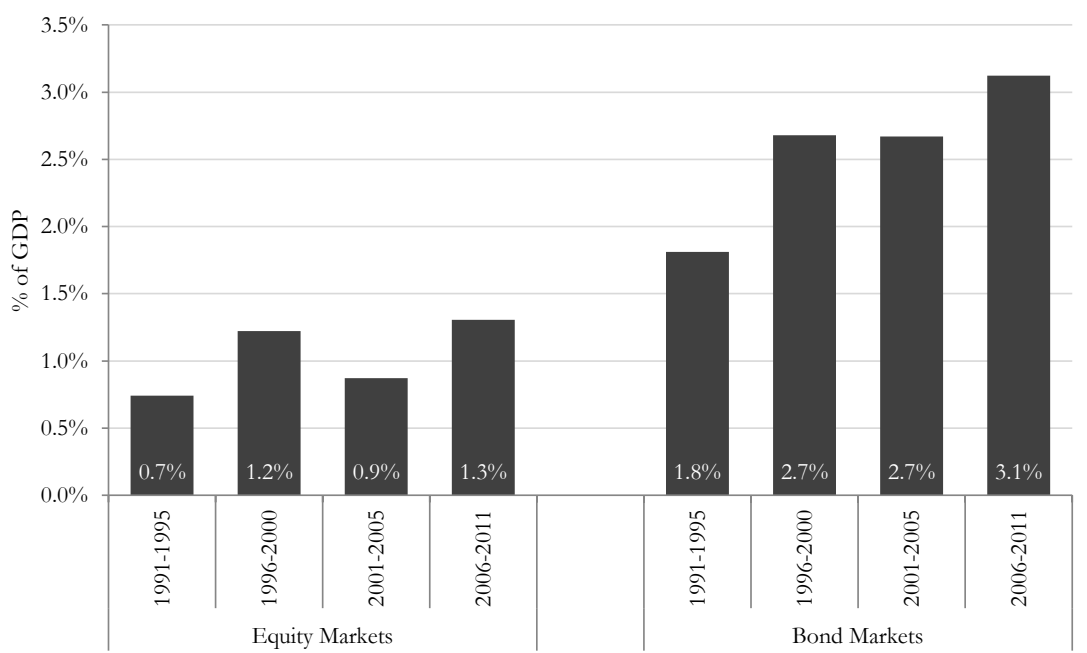

B. Number of Issuing Firms

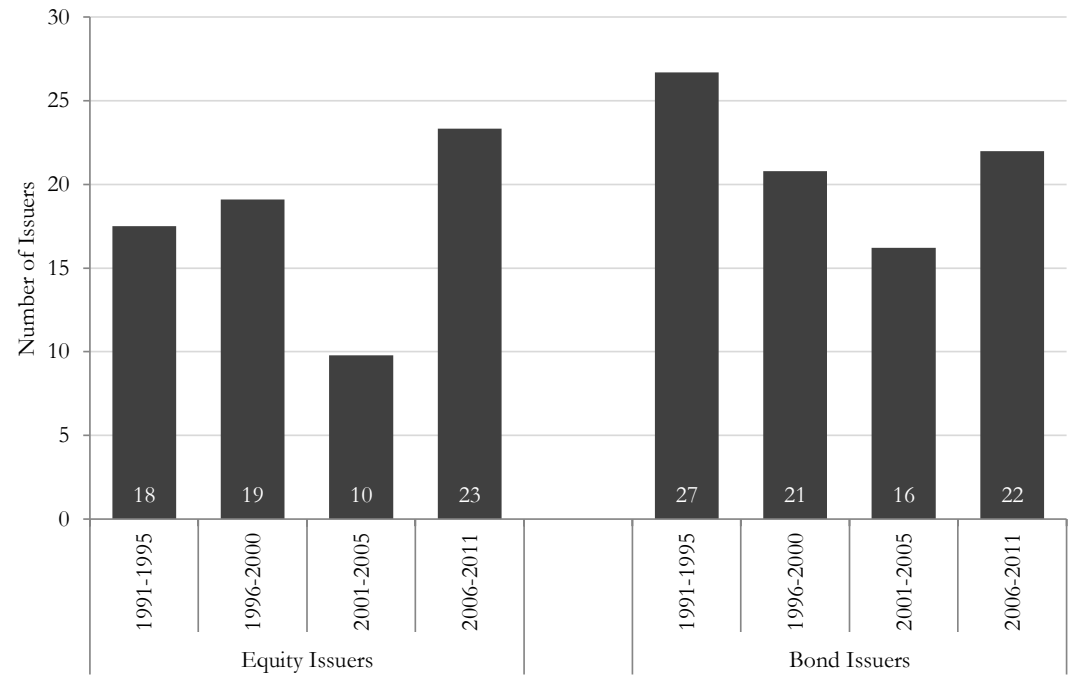

C. Concentration in Equity and Bond Markets

Amount Raised by the Top-5, Top-10, and Top-20 Issuing Firms

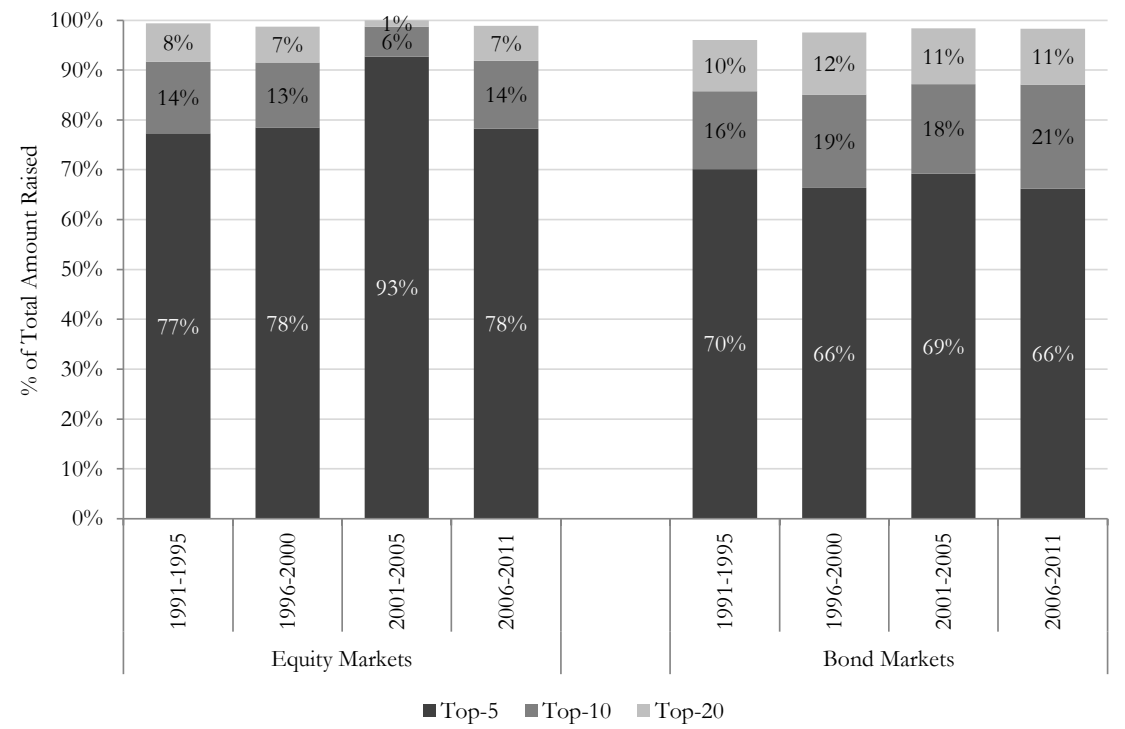




\section{Figure 3. CONCENTRATION IN SALES AND AMOUNT RAISED}

This figure shows in panel A the median concentration in sales for the top-5, top-10, and top-20 firms (using sales per year to define the top firms). Panel B shows the median concentration in the amount raised in capital markets by the same set of top firms as in panel A. Panel C shows the median concentration in sales for the top-5, top-10, and top-20 issuing firms (using amount raised per year to define the top issuers). All the measures are calculated as the median across countries of the average across years by country.

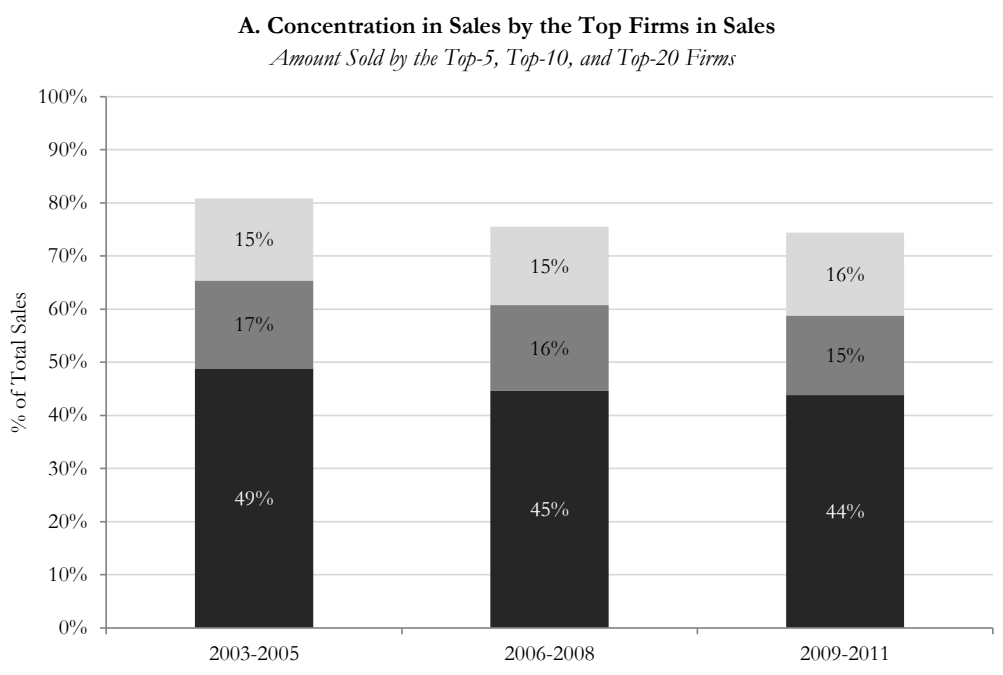

B. Concentration in the Amount Raised by the Top Firms in Sales Amount Raised by the Top-5, Top-10, and Top-20 Firms

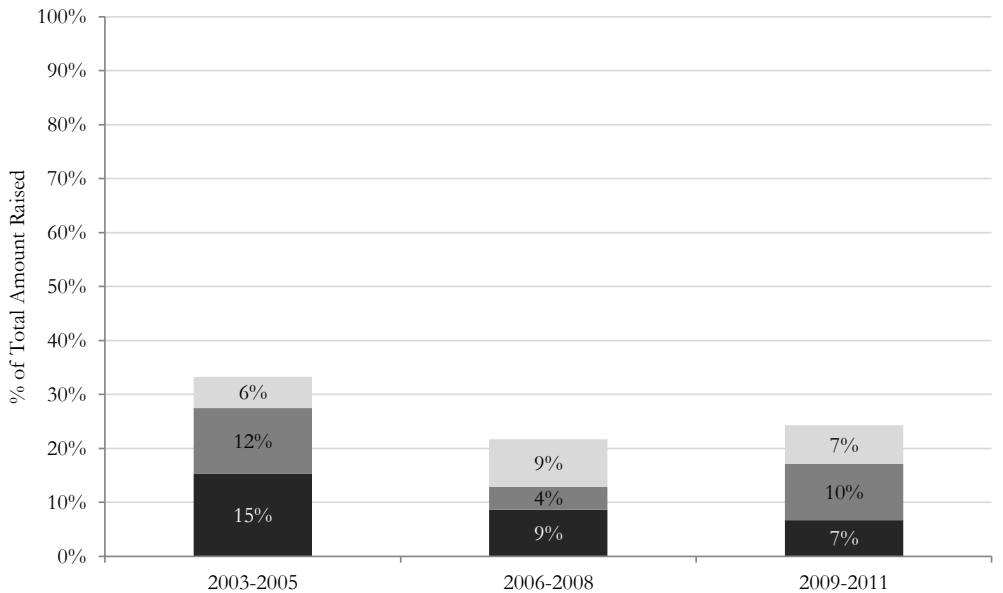

C. Concentration in Sales by the Top Issuing Firms

Amount Sold by the Top-5, Top-10, and Top-20 Issuing Firms

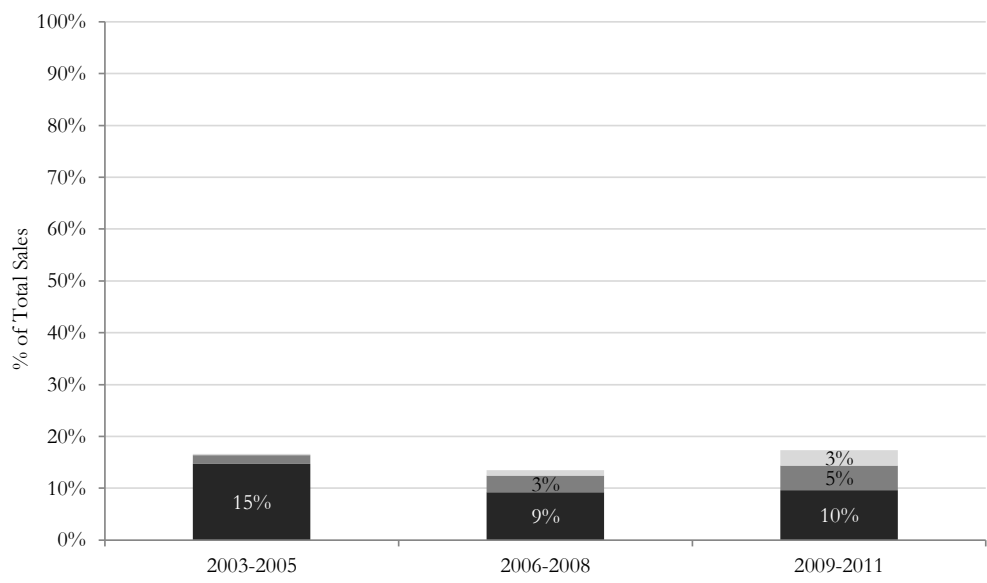

- Top-5 $=$ Top-10 $=$ Top-20 
FIGURE 4. FIRM SIZE DISTRIBUTION

This figure shows the estimated kernel distributions for firm size for issuing and non-issuing firms in 2003 and 2010 . Panel A uses the $\log$ of total assets as a proxy for size, whereas panels B and C use the $\log$ of sales and the $\log$ of the number of employees, respectively. Issuing firms are those that raised capital through equity or bonds between 2003 and 2010. Firms that issued equity or bonds only in 2011 are excluded from this figure. Non-issuers are the other firms in our sample. Only firms with data in both 2003 and 2010 are included in this figure. The kernel type used is a Gaussian with a band-width of 1.5.

\section{A. Total Assets}

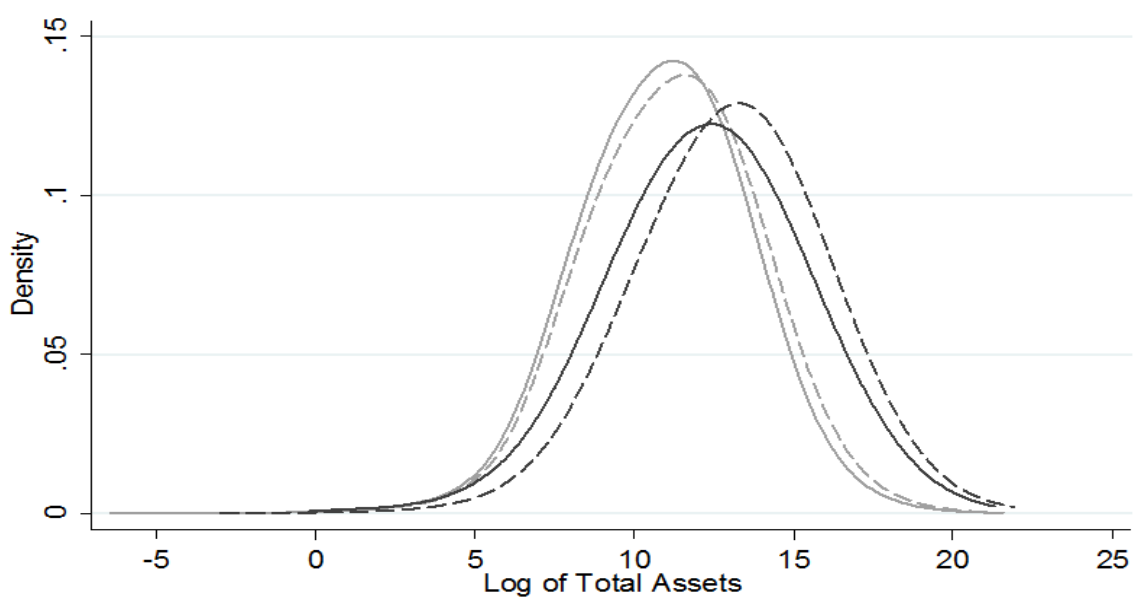

B. Sales

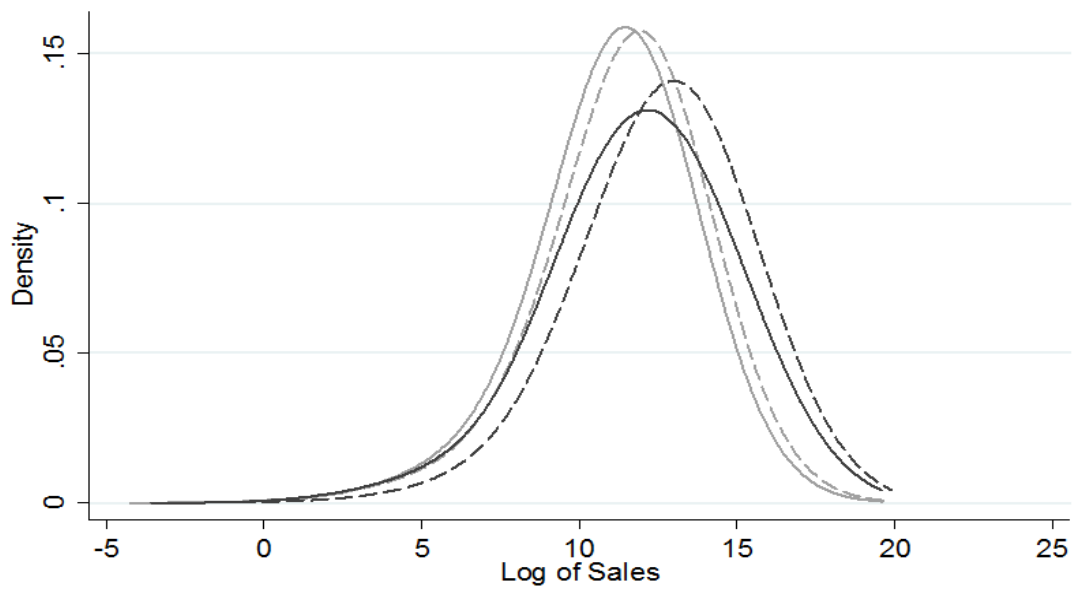

C. Number of Employees

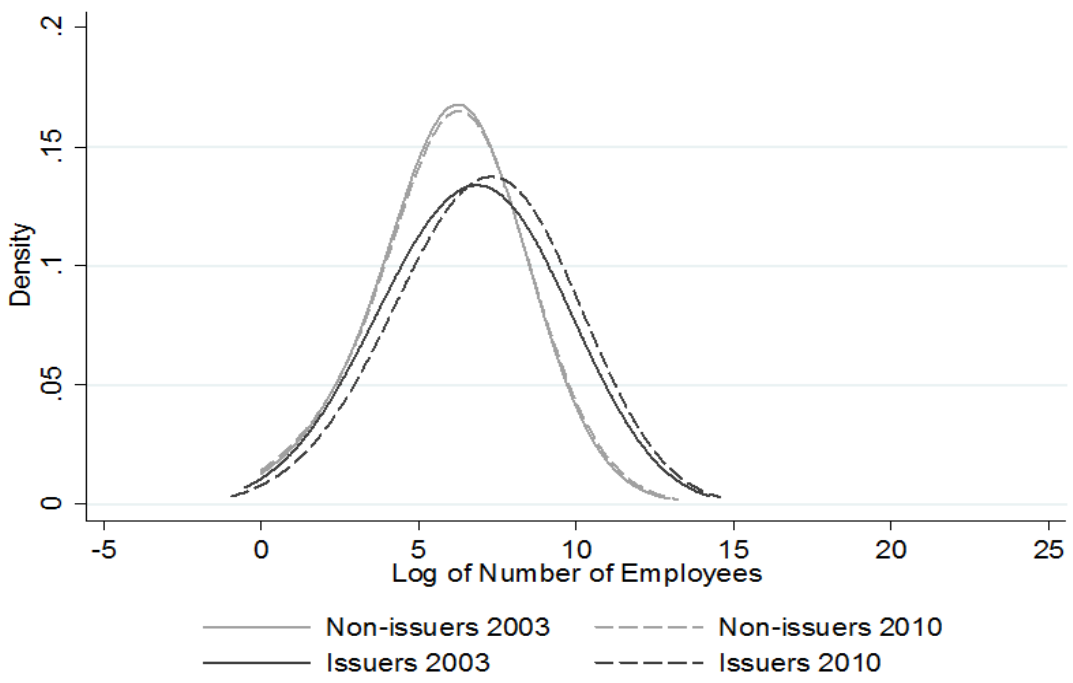


FIGURE 5. QUANTILE REGRESSION ESTIMATES

This figure shows the cumulative growth rates between 2003 and 2010 implied by the estimated quantile regression coefficients for each decile of the distribution of firm size. Dashed lines represent confidence intervals at the $95 \%$ statistical confidence level. Issuing firms are those that raised capital through equity or bonds between 2003 and 2010. Firms that issued only in 2011 are excluded from this figure. Non-issuers are the other firms in our sample.

\section{A. Total Assets}

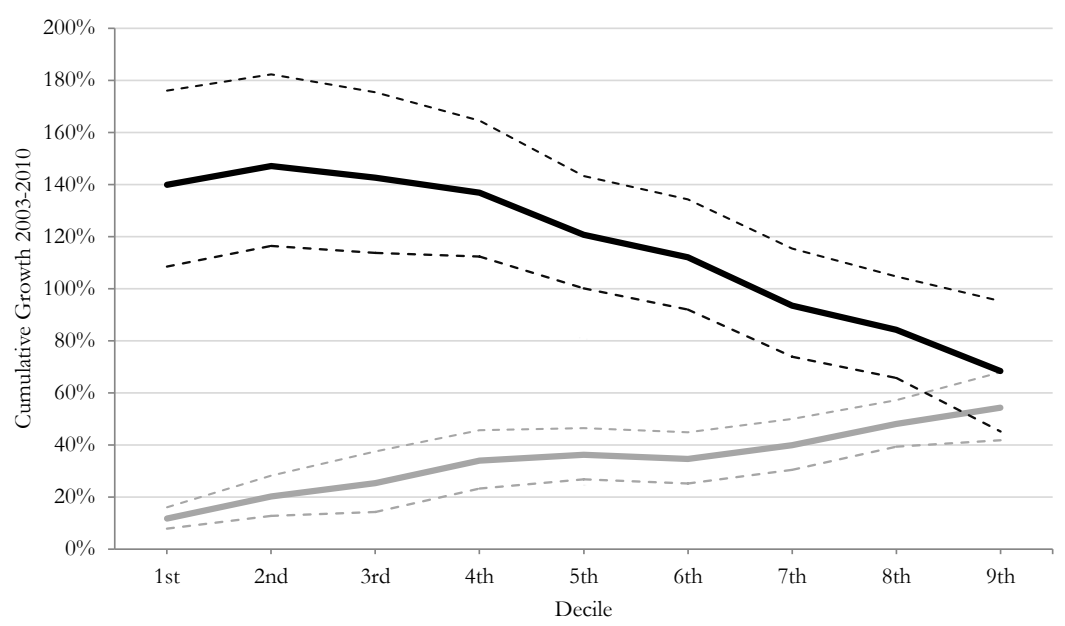

B. Sales

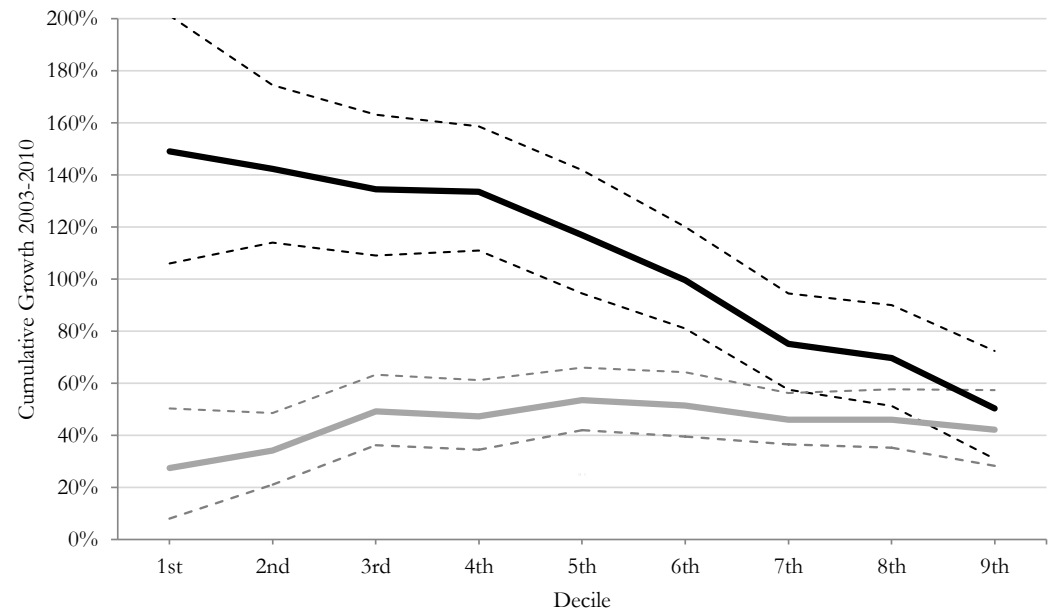

C. Number of Employees

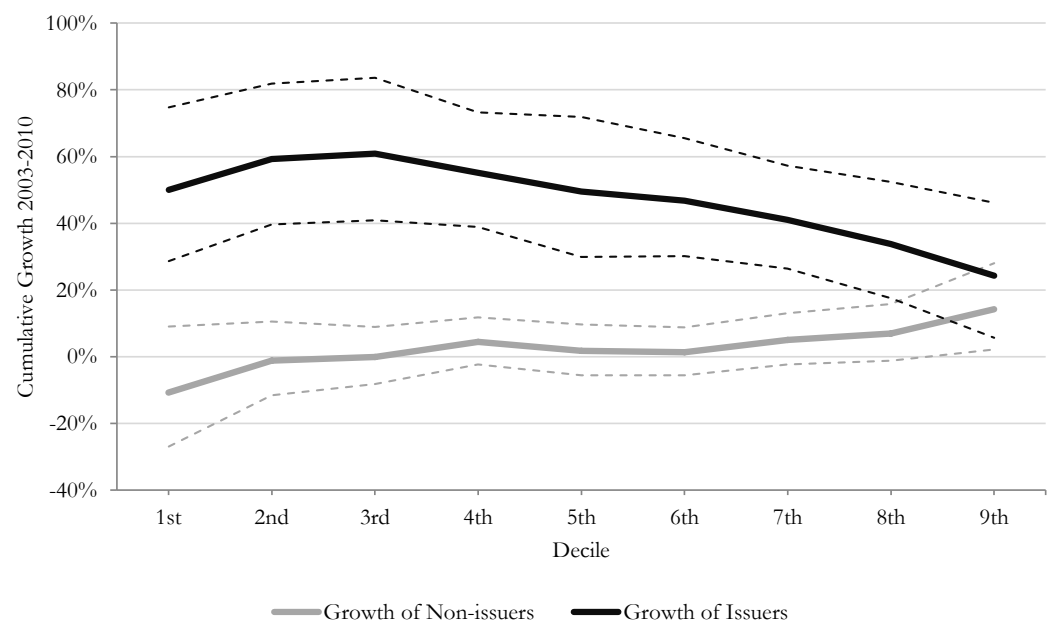




\section{FiguRE 6. EVENT STUDIES}

This figure shows the difference (in percentage points, p.p.) in the average annual growth rate of total assets for issuers relative to non-issuers for the 2003-2010 period. Time 0 represents the year of the first issuance for issuing firms. Issuing firms are those that raised capital through equity or bonds between 2003 and 2010. Firms that issued only in 2011 are excluded from this figure. Non-issuers are the other firms in our sample.

\section{A. 2004-2006 Issuers vs. Non-issuers}

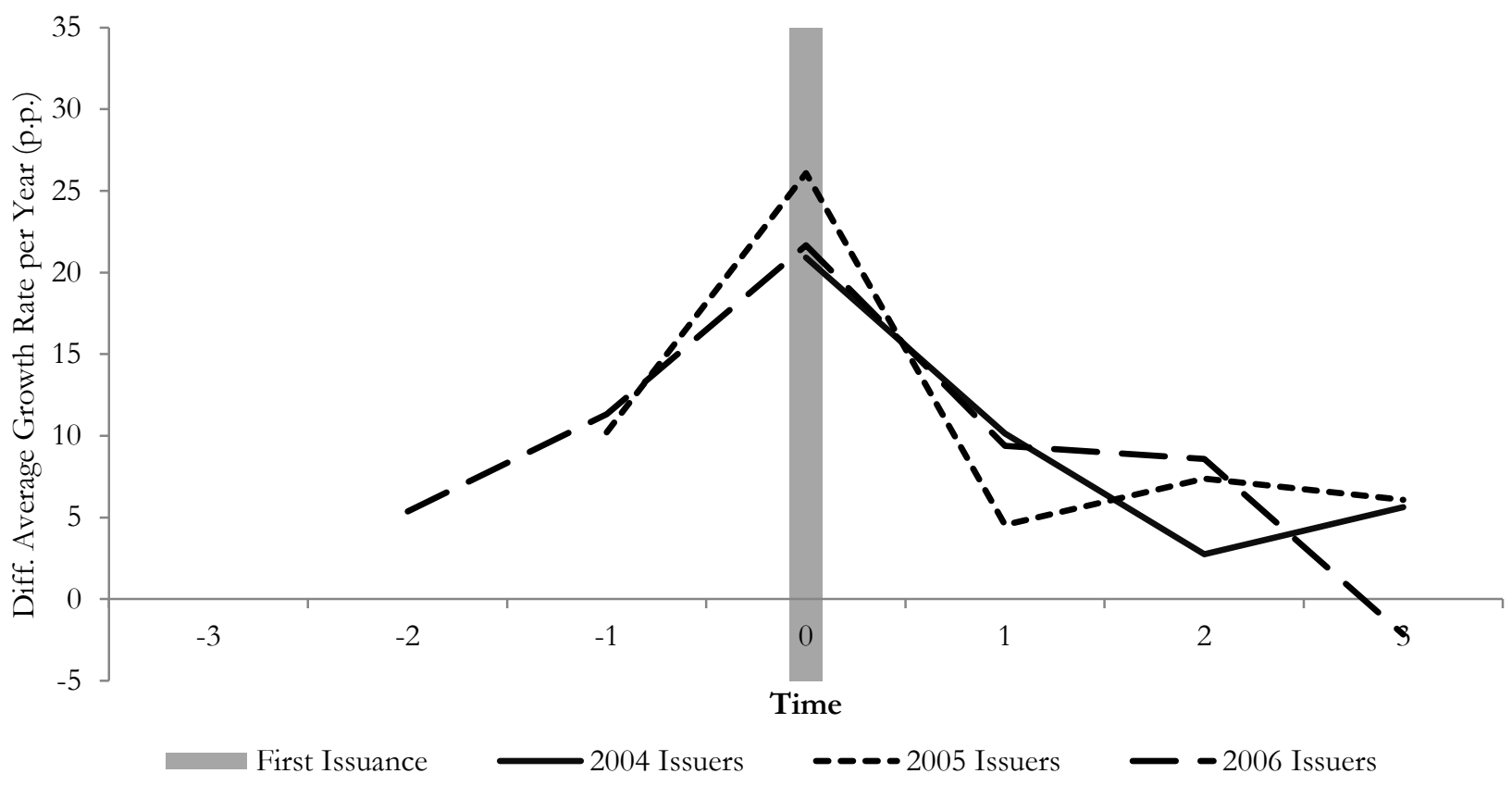

\section{B. 2007-2009 Issuers vs. Non-issuers}

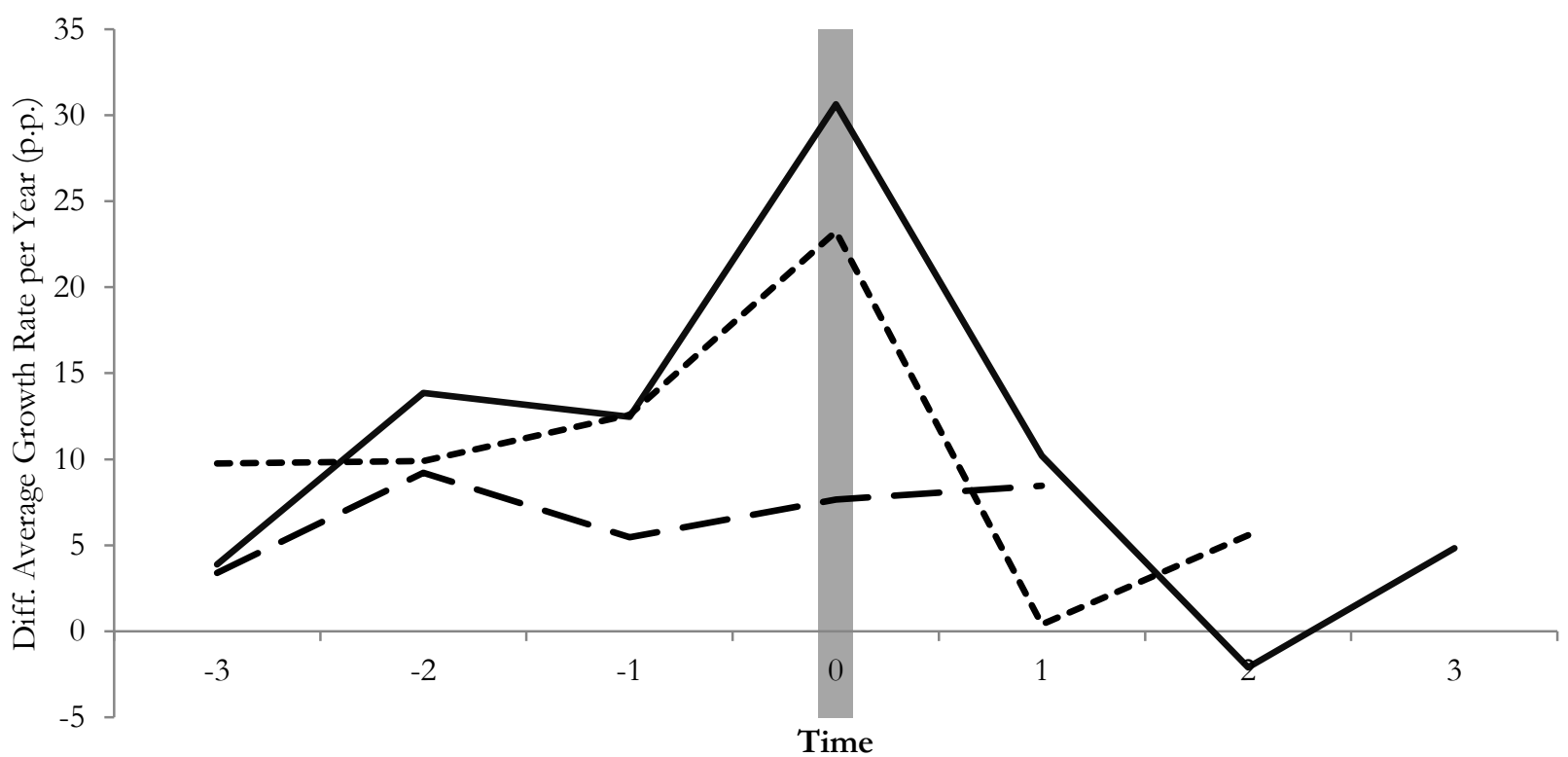

First Issuance 


\section{TABle 1. Firm CHARACTERISTICS}

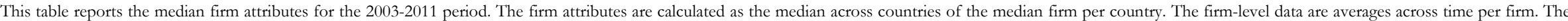

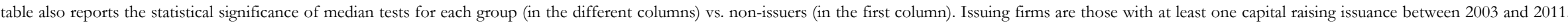

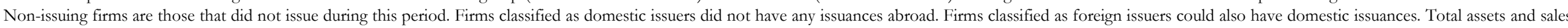
are reported in thousands of 2011 U.S. dollars. $*, *$, and $* * *$ denote statistical significance at $10 \%, 5 \%$, and $1 \%$, respectively.

\begin{tabular}{|c|c|c|c|c|c|c|c|c|}
\hline & Non-issuers & Issuers & Equity Issuers & Bond Issuers & $\begin{array}{c}\text { Domestic Equity } \\
\text { Issuers } \\
\end{array}$ & $\begin{array}{c}\text { Domestic Bond } \\
\text { Issuers }\end{array}$ & $\begin{array}{c}\text { Foreign Equity } \\
\text { Issuers }\end{array}$ & $\begin{array}{l}\text { Foreign Bond } \\
\text { Issuers }\end{array}$ \\
\hline Total Assets & 99,823 & $316,528 * * *$ & $255,701 * * *$ & $3,685,394 * * *$ & $230,066 * * *$ & $1,487,168 * * *$ & $318,051 * * *$ & $4,905,160 * * *$ \\
\hline Sales & 73,700 & $132,457 * * *$ & $114,015 * *$ & $1,011,641 * * *$ & $120,982 * * *$ & $531,643 * * *$ & $105,485 * *$ & $1,466,253 * * *$ \\
\hline Number of Employees & 327 & $705 * * *$ & $470 * * *$ & $3,080 * * *$ & $474 * * *$ & $2,029 * * *$ & $1,300 * * *$ & $4,746 * * *$ \\
\hline Asset Growth & $4.31 \%$ & $9.29 \% * * *$ & $10.48 \% * * *$ & $9.43 \% * * *$ & $10.05 \% * * *$ & $10.09 \% * * *$ & $11.04 \% * * *$ & $8.87 \% * * *$ \\
\hline Sales Growth & $5.48 \%$ & $9.37 \% * * *$ & $9.48 \% * * *$ & $8.68 \% * * *$ & $9.07 \% * * *$ & $9.45 \% * * *$ & $11.80 \% * * *$ & $7.44 \% * * *$ \\
\hline Employee Growth & $0.87 \%$ & $4.44 \% * * *$ & $4.97 \% * * *$ & $4.18 \% * * *$ & $4.56 \% * * *$ & $3.73 \% * * *$ & $6.46 \% * * *$ & $4.25 \% * * *$ \\
\hline Leverage & $49.36 \%$ & $55.33 \% * * *$ & $54.18 \% * * *$ & $60.55 \% * * *$ & $54.35 \% * * *$ & $61.50 \% * * *$ & $53.66 \%$ & $60.40 \% * * *$ \\
\hline Long-term Debt/Total Liabilities & $14.75 \%$ & $22.48 \% * * *$ & $21.50 \% * * *$ & $36.29 \% * * *$ & $20.01 \% * * *$ & $33.26 \% * * *$ & $19.96 \% * * *$ & $39.53 \% * * *$ \\
\hline Retained Earnings/Total Assets & $5.56 \%$ & $6.05 \% * *$ & $4.42 \% * *$ & $8.64 \% * *$ & $4.38 \% * *$ & $9.01 \%$ & $3.65 \%$ & $10.45 \% * *$ \\
\hline ROA & $3.66 \%$ & $3.59 \%$ & $3.06 \% * *$ & $4.00 \%$ & $3.07 \% * *$ & $3.46 \%$ & $2.86 \% * *$ & $3.61 \%$ \\
\hline Firm Age (in 2011) & 26 & $20 * * *$ & $19 * * *$ & 32 & $19 * * *$ & 25 & $17 * * *$ & 35 \\
\hline Number of Firms & 27,185 & 18,342 & 16,198 & 4,877 & 14,849 & 3,192 & 1,349 & 1,859 \\
\hline Percentage of Total Firms & $59.71 \%$ & $40.29 \%$ & $35.58 \%$ & $10.71 \%$ & $32.62 \%$ & $7.01 \%$ & $2.96 \%$ & $4.08 \%$ \\
\hline No. of Observations for Total Assets & 191,616 & 133,869 & 116,268 & 40,059 & 106,712 & 25,936 & 9,556 & 15,347 \\
\hline
\end{tabular}


TABle 2. Probability of Capital RaIsing ACtivity

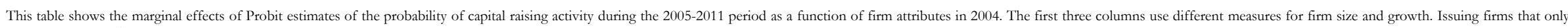

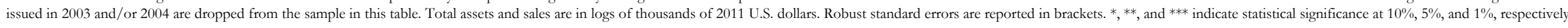

\begin{tabular}{|c|c|c|c|c|c|c|c|c|c|}
\hline & All Issuers & All Issuers & All Issuers & Equity Issuers & Bond Issuers & $\begin{array}{c}\text { Domestic Equity } \\
\text { Issuers }\end{array}$ & $\begin{array}{c}\text { Domestic Bond } \\
\text { Issuers }\end{array}$ & $\begin{array}{c}\text { Foreign Equity } \\
\text { Issuers }\end{array}$ & $\begin{array}{c}\begin{array}{c}\text { Foreign Bond } \\
\text { Issuers }\end{array} \\
\end{array}$ \\
\hline Proxy for Firm Size and Growth & Total Assets & Sales & Number of Employees & Total Assets & Total Assets & Total Assets & Total Assets & Total Assets & Total Assets \\
\hline \multicolumn{10}{|l|}{ Independent Variables } \\
\hline Size & $\begin{array}{l}0.0660 * * * \\
{[0.002]}\end{array}$ & $\begin{array}{l}0.0502 * * * \\
{[0.002]}\end{array}$ & $\begin{array}{l}0.0461 * * * \\
{[0.003]}\end{array}$ & $\begin{array}{l}0.0105 * * * \\
{[0.002]}\end{array}$ & $\begin{array}{l}0.0739 * * * \\
{[0.002]}\end{array}$ & $\begin{array}{l}0.0305 * * * \\
{[0.002]}\end{array}$ & $\begin{array}{l}0.0633 * * * \\
{[0.002]}\end{array}$ & $\begin{array}{l}0.0058 \text { *** } \\
{[0.001]}\end{array}$ & $\begin{array}{l}0.0299 \text { *** } \\
{[0.002]}\end{array}$ \\
\hline Growth & $\begin{array}{l}0.0010 * * * \\
{[0.000]}\end{array}$ & $\begin{array}{l}0.0005 \text { *** } \\
{[0.000]}\end{array}$ & $\begin{array}{l}0.0009 \text { *** } \\
{[0.000]}\end{array}$ & $\begin{array}{l}0.0010 \text { *** } \\
{[0.000]}\end{array}$ & $\begin{array}{l}0.0003 * * * \\
{[0.000]}\end{array}$ & $\begin{array}{l}0.0009 \text { *** } \\
{[0.000]}\end{array}$ & $\begin{array}{l}0.0006 * * * \\
{[0.000]}\end{array}$ & $\begin{array}{l}0.0002 * * * \\
{[0.000]}\end{array}$ & $\begin{array}{l}0.0001 \text { *** } \\
{[0.000]}\end{array}$ \\
\hline Leverage & $\begin{array}{l}0.0002 * * \\
{[0.000]}\end{array}$ & $\begin{array}{l}0.0000 \\
{[0.000]}\end{array}$ & $\begin{array}{r}-0.0001 \\
{[0.000]}\end{array}$ & $\begin{array}{l}0.0000 \\
{[0.000]}\end{array}$ & $\begin{array}{l}0.0001 \text { *** } \\
{[0.000]}\end{array}$ & $\begin{array}{l}0.0001 * \\
{[0.000]}\end{array}$ & $\begin{array}{l}0.0001 \text { ** } \\
{[0.000]}\end{array}$ & $\begin{array}{l}-0.0001 * \\
{[0.000]}\end{array}$ & $\begin{array}{l}0.0001 \text { *** } \\
{[0.000]}\end{array}$ \\
\hline Long-term Debt/Total Liabilities & $\begin{array}{l}0.0025 \text { *** } \\
{[0.000]}\end{array}$ & $\begin{array}{l}0.0037^{* * *} \\
{[0.000]}\end{array}$ & $\begin{array}{l}0.0046 * * * \\
{[0.000]}\end{array}$ & $\begin{array}{l}0.0021 \text { *** } \\
{[0.000]}\end{array}$ & $\begin{array}{l}0.0013 \text { *** } \\
{[0.000]}\end{array}$ & $\begin{array}{l}0.0024 \text { *** } \\
{[0.000]}\end{array}$ & $\begin{array}{l}0.0015 \text { *** } \\
{[0.000]}\end{array}$ & $\begin{array}{l}0.0001 \\
{[0.000]}\end{array}$ & $\begin{array}{l}0.0008 \text { *** } \\
{[0.000]}\end{array}$ \\
\hline $\mathrm{ROA}$ & $\begin{array}{l}-0.0040 * * * \\
{[0.000]}\end{array}$ & $\begin{array}{l}-0.0037 * * * \\
{[0.000]}\end{array}$ & $\begin{array}{l}-0.0039 \text { *** } \\
{[0.000]}\end{array}$ & $\begin{array}{l}-0.0036 * * * \\
{[0.000]}\end{array}$ & $\begin{array}{l}-0.0018 * * * \\
{[0.000]}\end{array}$ & $\begin{array}{l}-0.0036 * * * \\
{[0.000]}\end{array}$ & $\begin{array}{l}-0.0025 * * * \\
{[0.000]}\end{array}$ & $\begin{array}{l}-0.0006 * * * \\
{[0.000]}\end{array}$ & $\begin{array}{r}-0.0003 \\
{[0.000]}\end{array}$ \\
\hline Country Dummies & Yes & Yes & Yes & Yes & Yes & Yes & Yes & Yes & Yes \\
\hline No. of Observations & 16,177 & 15,290 & 10,840 & 16,177 & 15,966 & 14,430 & 10,462 & 8,551 & 10,009 \\
\hline Predicted Probability & $43.3 \%$ & $43.8 \%$ & $46.5 \%$ & $33.9 \%$ & $18.4 \%$ & $35.0 \%$ & $17.6 \%$ & $5.0 \%$ & $10.5 \%$ \\
\hline
\end{tabular}




\section{TABLE 3. QUANTILE AND MEAN REgRESSIONS}

This table reports quantile and mean regressions of firm size on a constant, a dummy variable for 2010 , a dummy variable for issuing firms, and an interaction term of these two dummies. The table also shows the average annual growth rates implied by these Firms that issued only in 2011 asung excluded from this thente. Panel A uses the data on firm size at two points in time (2003 and 2010 ) for all firms with data in both years. Issuing firms are those that raised capital through equity or bonds between 2003 and 2010. in logs. All coefficients are reported in exponential form. Standard errors, shown in brackets, are bootstrapped (using 400 replications) and clustered at the firm-level. ***, and *** denote statistical significance at 10\%, $5 \%$, and $1 \%$, respectively.

\begin{tabular}{|c|c|c|c|c|c|c|c|c|c|c|}
\hline \multicolumn{11}{|c|}{ A. Total Assets } \\
\hline & \multicolumn{9}{|c|}{ Quantile Regressions } & \multirow{2}{*}{$\begin{array}{c}\text { Mean } \\
\text { Regression }\end{array}$} \\
\hline & 1st Decile & 2nd Decile & 3rd Decile & 4th Decile & 5th Decile & 6th Decile & 7th Decile & 8th Decile & 9th Decile & \\
\hline Constant & $3,517 * * *$ & $6,607 * * *$ & $15,067 * * *$ & $32,302 * * *$ & $64,710 * * *$ & $119,101 * * *$ & $207,537 * * *$ & $386,444 * * *$ & $893,746 * * *$ & $55,443 * * *$ \\
\hline (Size of Non-issuers in 2003) & [51] & [154] & [493] & [940] & {$[1,542]$} & {$[2,894]$} & {$[4,370]$} & {$[8,202]$} & {$[24,998]$} & {$[1,083]$} \\
\hline Issuer Dummy & $1.631 * * *$ & $2.919 * * *$ & $3.154 * * *$ & $3.349 * * *$ & $3.532 * * *$ & $4.031 * * *$ & $4.915 * * *$ & $6.318 * * *$ & $9.468 * * *$ & $3.806 * * *$ \\
\hline (Relative Size of Issuers vs. Non-issuers in 2003) & {$[0.085]$} & {$[0.137]$} & {$[0.172]$} & [0.153] & [0.146] & {$[0.165]$} & [0.195] & [0.271] & {$[0.573]$} & {$[0.138]$} \\
\hline 2010 Dummy & $1.118 * * *$ & $1.202 * * *$ & $1.253 * *$ & $1.340 * * *$ & $1.362 * * *$ & $1.346 * *$ & $1.398 * * *$ & $1.480 * * *$ & $1.543 * * *$ & $1.340 * *$ \\
\hline (Relative Size of Non-issuers in 2010 vs. 2003) & {$[0.021]$} & {$[0.040]$} & {$[0.059]$} & {$[0.057]$} & {$[0.050]$} & {$[0.050]$} & {$[0.050]$} & {$[0.045]$} & {$[0.067]$} & {$[0.013]$} \\
\hline Issuer Dummy x 2010 Dummy & $2.145 * * *$ & $2.056 * * *$ & $1.936 * * *$ & $1.768 * * *$ & $1.620 * * *$ & $1.575 * * *$ & $1.384 * * *$ & $1.245 * * *$ & 1.091 & $1.621 * * *$ \\
\hline (Relative Growth of Issuers vs. Non-issuers) & {$[0.153]$} & {$[0.145]$} & {$[0.150]$} & [0.121] & {$[0.096]$} & {$[0.092]$} & {$[0.083]$} & {$[0.078]$} & {$[0.091]$} & {$[0.027]$} \\
\hline Average Growth of Non-issuers & $1.6 \%$ & $2.7 \%$ & $3.3 \%$ & $4.3 \%$ & $4.5 \%$ & $4.3 \%$ & $4.9 \%$ & $5.8 \%$ & $6.4 \%$ & $4.3 \%$ \\
\hline Average Growth of Issuers & $13.3 \%$ & $13.8 \%$ & $13.5 \%$ & $13.1 \%$ & $12.0 \%$ & $11.3 \%$ & $9.9 \%$ & $9.1 \%$ & $7.7 \%$ & $11.7 \%$ \\
\hline $\begin{array}{l}\text { No. of Observations } \\
\text { R-squared }\end{array}$ & 47,596 & 47,596 & 47,596 & 47,596 & 47,596 & 47,596 & 47,596 & 47,596 & 47,596 & $\begin{array}{r}47,596 \\
0.09 \\
\end{array}$ \\
\hline \multicolumn{11}{|c|}{ B. Sales } \\
\hline & \multicolumn{9}{|c|}{ Quantile Regressions } & Mean \\
\hline & 1st Decile & 2nd Decile & 3rd Decile & 4th Decile & 5th Decile & 6th Decile & 7th Decile & 8th Decile & 9th Decile & Regression \\
\hline Constant & $4,087 * * *$ & $14,039 * * *$ & $27,785 * * *$ & $49,968 * * *$ & $82,380 * * *$ & $134,784^{* * *}$ & $226,677 * * *$ & $396,938 * * *$ & $905,572 * * *$ & $66,412 * * *$ \\
\hline (Size of Non-issuers in 2003) & [251] & [522] & [962] & {$[1,586]$} & {$[2,279]$} & {$[4,111]$} & {$[5,843]$} & {$[11,139]$} & {$[30,594]$} & {$[1,694]$} \\
\hline Issuer Dummy & $1.240 * *$ & $1.300 * * *$ & $1.523 * * *$ & 1.755 *** & $2.099 * * *$ & $2.491 * * *$ & $3.136 * * *$ & $3.818 * * *$ & $4.903 * * *$ & $2.247 * * *$ \\
\hline (Relative Size of Issuers us. Non-issuers in 2003) & {$[0.119]$} & {$[0.077]$} & {$[0.081]$} & {$[0.089]$} & {$[0.108]$} & {$[0.118]$} & {$[0.149]$} & {$[0.197]$} & {$[0.301]$} & {$[0.092]$} \\
\hline 2010 Dummy & $1.275 * * *$ & $1.342 * * *$ & $1.492 * * *$ & $1.473 * * *$ & $1.536 * * *$ & $1.515 * * *$ & $1.461 * * *$ & $1.461 * * *$ & $1.422 * * *$ & $1.425 * * *$ \\
\hline (Relative Size of Non-issuers in 2010 vs. 2003) & {$[0.108]$} & {$[0.070]$} & {$[0.069]$} & {$[0.068]$} & {$[0.061]$} & {$[0.063]$} & {$[0.050]$} & {$[0.057]$} & {$[0.074]$} & {$[0.020]$} \\
\hline Issuer Dummy x 2010 Dummy & $1.954 * * *$ & $1.806 * * *$ & $1.572 * * *$ & $1.586 * * *$ & $1.413 * * *$ & $1.319 * * *$ & $1.198 * * *$ & $1.161 * *$ & 1.057 & $1.465 * * *$ \\
\hline (Relative Growth of Issuers vs. Non-issuers) & {$[0.248]$} & {$[0.152]$} & {$[0.116]$} & {$[0.112]$} & {$[0.097]$} & {$[0.084]$} & {$[0.075]$} & {$[0.084]$} & {$[0.096]$} & [0.032] \\
\hline Average Growth of Non-issuers & $3.5 \%$ & $4.3 \%$ & $5.9 \%$ & $5.7 \%$ & $6.3 \%$ & $6.1 \%$ & $5.6 \%$ & $5.6 \%$ & $5.2 \%$ & $5.2 \%$ \\
\hline Average Growth of Issuers & $13.9 \%$ & $13.5 \%$ & $13.0 \%$ & $12.9 \%$ & $11.7 \%$ & $10.4 \%$ & $8.3 \%$ & $7.8 \%$ & $6.0 \%$ & $11.1 \%$ \\
\hline $\begin{array}{l}\text { No. of Observations } \\
\text { R-squared }\end{array}$ & 31,404 & 31,404 & 31,404 & 31,404 & 31,404 & 31,404 & 31,404 & 31,404 & 31,404 & $\begin{array}{r}31,404 \\
0.05\end{array}$ \\
\hline \multicolumn{11}{|c|}{ C. Number of Employees } \\
\hline & \multicolumn{9}{|c|}{ Quantile Regressions } & Mean \\
\hline & 1st Decile & 2nd Decile & 3rd Decile & 4th Decile & 5th Decile & 6th Decile & 7th Decile & 8th Decile & 9th Decile & Regression \\
\hline Constant & $28^{* * *}$ & $91 * * *$ & $175^{* * *}$ & $290 * * *$ & $456^{* * *}$ & $718^{* * *}$ & $1,121 * * *$ & 1,897 *** & $4,057^{* * *}$ & $390 * * *$ \\
\hline (Size of Non-issuers in 2003) & [1.812] & {$[3.215]$} & [4.527] & {$[7.205]$} & {$[12.360]$} & {$[16.001]$} & {$[31.407]$} & {$[59.715]$} & {$[158.317]$} & {$[9.298]$} \\
\hline Issuer Dummy & 1.071 & 1.000 & $1.183 * * *$ & $1.483 * * *$ & $1.871 * * *$ & $2.315 * * *$ & $2.927 * * *$ & $3.637 * * *$ & $4.962 * * *$ & $2.037 * * *$ \\
\hline (Relative Size of Issuers us. Non-issuers in 2003) & {$[0.087]$} & {$[0.061]$} & {$[0.069]$} & {$[0.070]$} & {$[0.112]$} & {$[0.122]$} & {$[0.142]$} & {$[0.217]$} & {$[0.382]$} & {$[0.084]$} \\
\hline 2010 Dummy & 0.893 & 0.989 & 1.000 & 1.045 & 1.018 & 1.014 & 1.051 & $1.070 *$ & $1.143 * *$ & $1.021 *$ \\
\hline (Relative Size of Non-issuers in $2010 \mathrm{vs.2003)}$ & {$[0.091]$} & {$[0.056]$} & {$[0.043]$} & {$[0.036]$} & {$[0.039]$} & {$[0.037]$} & {$[0.039]$} & {$[0.043]$} & {$[0.066]$} & {$[0.012]$} \\
\hline Issuer Dummy x 2010 Dummy & $1.680 * * *$ & $1.611 * * *$ & $1.609 * * *$ & $1.485 * * *$ & $1.469 * * *$ & $1.448 * *$ & $1.342 * * *$ & $1.251 * * *$ & 1.087 & $1.417 * * *$ \\
\hline (Relative Growth of Issuers vs. Non-issuers) & {$[0.225]$} & {$[0.150]$} & {$[0.138]$} & {$[0.105]$} & {$[0.122]$} & {$[0.109]$} & {$[0.095]$} & {$[0.100]$} & {$[0.117]$} & {$[0.026]$} \\
\hline Average Growth of Non-issuers & $-1.6 \%$ & $-0.2 \%$ & $0.0 \%$ & $0.6 \%$ & $0.3 \%$ & $0.2 \%$ & $0.7 \%$ & $1.0 \%$ & $1.9 \%$ & $0.3 \%$ \\
\hline Average Growth of Issuers & $6.0 \%$ & $6.9 \%$ & $7.0 \%$ & $6.5 \%$ & $5.9 \%$ & $5.6 \%$ & $5.0 \%$ & $4.3 \%$ & $3.1 \%$ & $5.4 \%$ \\
\hline $\begin{array}{l}\text { No. of Observations } \\
\text { R-squared }\end{array}$ & 24,996 & 24,996 & 24,996 & 24,996 & 24,996 & 24,996 & 24,996 & 24,996 & 24,996 & $\begin{array}{r}24,996 \\
0.04\end{array}$ \\
\hline
\end{tabular}




\section{TABle 4. Cumulative Growth DifFERENTIAL AND INTER-QUANTILE EQUALITY TESTS}

This table reports the cumulative growth differential between selected deciles (in percentage points) implied by the coefficient estimates shown in Table 3, separately for non-issuing firms, issuing firms, and the relative growth between issuing and non-issuing firms. The table also reports the statistical significance of inter-quantile equality tests. *, **, and *** denote statistical significance at $10 \%, 5 \%$, and $1 \%$, respectively. D1 denotes the $1^{\text {st }}$ decile, D2 the $2^{\text {nd }}$ decile, and so forth.

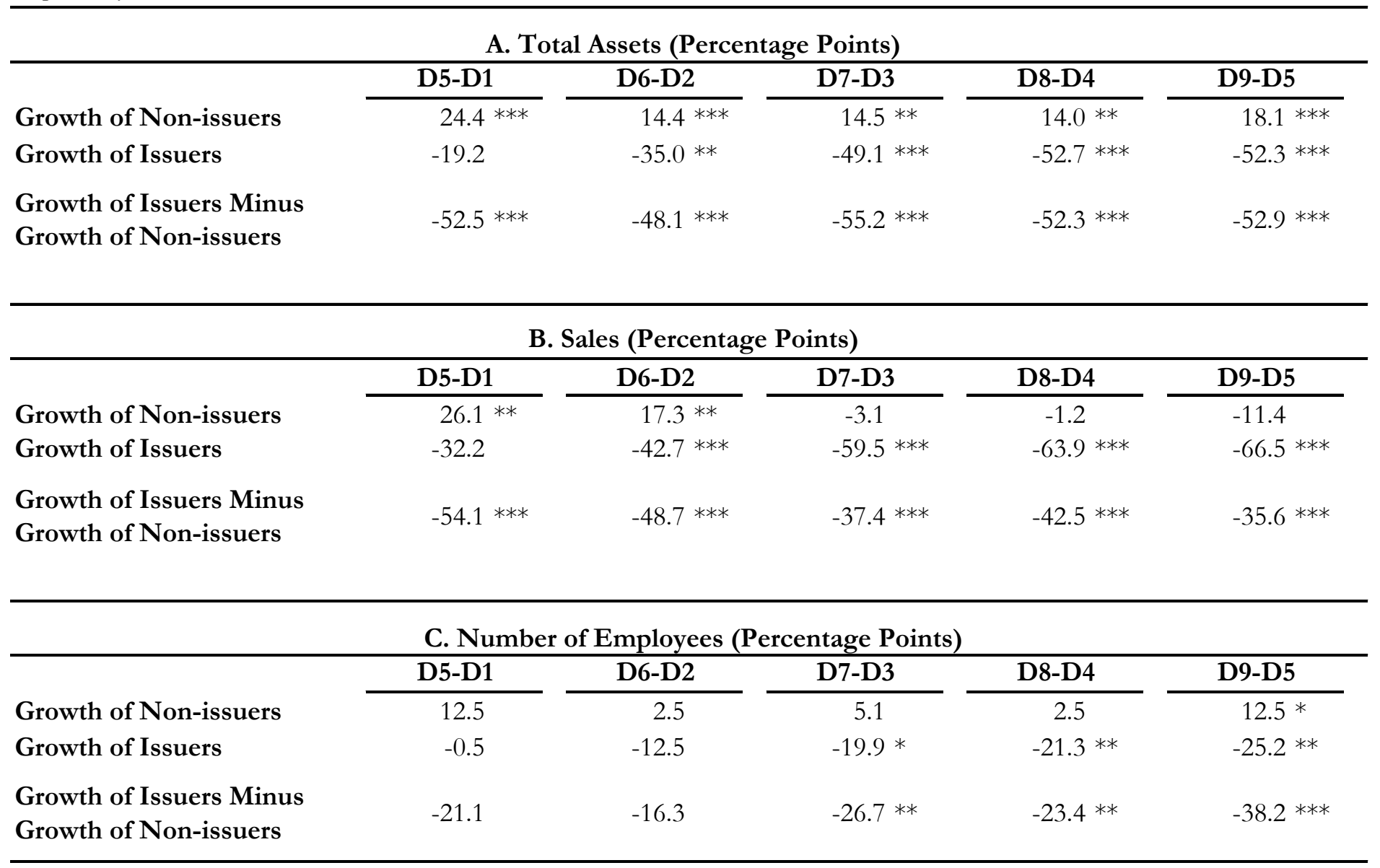




\section{TABLE 5. 2003-2010 GROWTH AS A FUNCTION OF INITIAL SIZE}

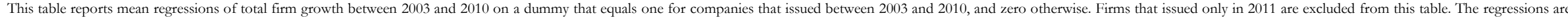

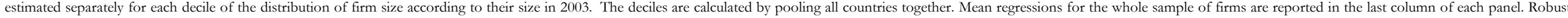
standard errors are reported in brackets. $* *$, and $* * *$ denote statistical significance at $10 \%, 5 \%$, and $1 \%$, respectively.

\begin{tabular}{|c|c|c|c|c|c|c|c|c|c|c|c|}
\hline \multicolumn{12}{|c|}{ A. Total Assets } \\
\hline \multirow[b]{3}{*}{ Issuer Dummy } & \multicolumn{10}{|c|}{ Inter-decile Range } & \multirow[b]{2}{*}{ All Firms } \\
\hline & $<1$ st & 1st-2nd & 2nd-3rd & 3rd-4th & 4th-5th & 5th-6th & 6th-7th & 7th-8th & 8th-9th & $>9$ th & \\
\hline & $\begin{array}{l}1.233 \text { *** } \\
{[0.160]}\end{array}$ & $\begin{array}{rl}0.820 & * * * \\
{[0.105]} & \end{array}$ & $\begin{array}{l}0.6955^{* * *} \\
{[0.081]}\end{array}$ & $\begin{array}{r}0.4955^{* * *} \\
{[0.058]}\end{array}$ & $\begin{array}{r}0.453 \\
{[0.047} \\
{[0.047}\end{array}$ & $\begin{array}{l}0.550 \text { *** } \\
{[0.041]}\end{array}$ & $\begin{array}{l}0.460 \text { *** } \\
{[0.037]}\end{array}$ & $\begin{array}{l}0.401{ }^{* * *} \\
{[0.032]}\end{array}$ & $\begin{array}{l}0.300 * * * \\
{[0.030]}\end{array}$ & $\begin{array}{r}0.168 \text { *** } \\
{[0.034]}\end{array}$ & $\begin{array}{rl}0.483 & * * * \\
{[0.017]} & \end{array}$ \\
\hline Country Fixed Effects & Yes & Yes & Yes & Yes & Yes & Yes & Yes & Yes & Yes & Yes & Yes \\
\hline No. of Observations & 2,379 & 2,380 & 2,380 & 2,380 & 2,380 & 2,380 & 2,380 & 2,380 & 2,380 & 2,379 & 23,798 \\
\hline R-squared & 0.20 & 0.16 & 0.13 & 0.12 & 0.14 & 0.16 & 0.16 & 0.18 & 0.21 & 0.21 & 0.09 \\
\hline \multicolumn{12}{|c|}{ B. Sales } \\
\hline \multicolumn{12}{|c|}{ Inter-decile Range } \\
\hline Issuer Dummy & $\begin{array}{c}<1 \text { st } \\
1.429^{* * *} \\
{[0.157]}\end{array}$ & $\begin{array}{c}\text { 1st-2nd } \\
0.652 * * * \\
{[0.080]}\end{array}$ & $\frac{\text { 2nd-3rd }}{0.463 * * *}$ & $\begin{array}{l}\text { 3rd-4th } \\
0.560^{* * *} \\
{[0.058]}\end{array}$ & $\begin{array}{c}\text { 4th-5th } \\
0.435 \text { *** } \\
{[0.056]}\end{array}$ & $\begin{array}{c}\text { 5th-6th } \\
0.429^{* * *} \\
{[0.049]}\end{array}$ & $\begin{array}{c}\text { 6th-7th } \\
0.392 * * * \\
{[0.043]}\end{array}$ & $\begin{array}{c}\text { 7th-8th } \\
0.303 \text { *** } \\
{[0.040]}\end{array}$ & $\begin{array}{c}\text { 8th-9th } \\
0.229 * * * \\
{[0.042]}\end{array}$ & $\begin{array}{r}>\text { 9)th } \\
0.041 \\
{[0.035]}\end{array}$ & $\begin{array}{c}\text { All Firms } \\
0.436^{* * *} \\
{[0.021]}\end{array}$ \\
\hline Country Fixed Effects & Yes & Yes & Yes & Yes & Yes & Yes & Yes & Yes & Yes & Yes & Yes \\
\hline No. of Observations & 1,569 & 1,571 & 1,570 & 1,571 & 1,570 & 1,570 & 1,571 & 1,570 & 1,570 & 1,570 & 15,702 \\
\hline R-squared & 0.13 & 0.08 & 0.07 & 0.14 & 0.11 & 0.13 & 0.15 & 0.16 & 0.17 & 0.17 & 0.06 \\
\hline \multicolumn{12}{|c|}{ C. Number of Employees } \\
\hline & & & & & Inter-de & ange & & & & & \\
\hline & $<1 \mathrm{st}$ & 1st-2nd & 2nd-3rd & 3rd-4th & 4th-5th & 5th-6th & 6th-7th & 7th-8th & 8th-9th & $>9 \mathrm{th}$ & All Firms \\
\hline Issuer Dummy & $\begin{array}{l}0.518 * * * \\
{[0.097]}\end{array}$ & $\begin{array}{l}0.398 * * * \\
{[0.067]}\end{array}$ & $\begin{array}{l}0.282 * * * \\
{[0.059]}\end{array}$ & $\begin{array}{l}0.292 * * * \\
{[0.060]}\end{array}$ & $\begin{array}{l}0.263 * * * \\
{[0.055]}\end{array}$ & $\begin{array}{l}0.335 * * * \\
{[0.056]}\end{array}$ & $\begin{array}{l}0.317 \text { *** } \\
{[0.047]}\end{array}$ & $\begin{array}{l}0.370 * * * \\
{[0.047]}\end{array}$ & $\begin{array}{l}0.208 * * * \\
{[0.046]}\end{array}$ & $\begin{array}{l}0.190 * * * \\
{[0.065]}\end{array}$ & $\begin{array}{l}0.2900^{* * *} \\
{[0.019]}\end{array}$ \\
\hline Country Fixed Effects & Yes & Yes & Yes & Yes & Yes & Yes & Yes & Yes & Yes & Yes & Yes \\
\hline No. of Observations & 1,233 & 1,251 & 1,263 & 1,251 & 1,250 & 1,249 & 1,252 & 1,250 & 1,250 & 1,249 & 12,498 \\
\hline R-squared & 0.08 & 0.14 & 0.11 & 0.16 & 0.09 & 0.13 & 0.14 & 0.14 & 0.11 & 0.09 & 0.05 \\
\hline
\end{tabular}




\section{TABLE 6. EVENT STUDY OF FIRMS DYNAMICS AROUND ISSUANCE ACTIVITY}

This table reports panel regressions of firm attributes on a seven-year window around the capital raising issuances that took place between 2003 and 2011. The seven-year windows are captured by a dummy variable for the issuance year, three dummies for the three preceding years, and three dummies for the three subsequent years. The regressions include firms with no issuances as part of the control group. Total assets and sales are in logs of thousands of 2011 U.S. dollars; number of employees is in logs. Standard errors, shown in brackets, are clustered at the country level. ${ }^{*}, * *$, and $* * *$ denote statistical significance at $10 \%, 5 \%$, and $1 \%$, respectively.

\begin{tabular}{|c|c|c|c|}
\hline \multicolumn{4}{|c|}{ A. Regressions in Levels } \\
\hline & Total Assets & Sales & $\begin{array}{l}\text { Number of } \\
\text { Employees }\end{array}$ \\
\hline \multirow[t]{2}{*}{ Issue year - 3} & $0.371 * *$ & 0.229 & $0.220 * * *$ \\
\hline & {$[0.142]$} & {$[0.146]$} & {$[0.081]$} \\
\hline \multirow[t]{2}{*}{ Issue year - 2} & $0.454 * * *$ & $0.343 * *$ & $0.266 * * *$ \\
\hline & {$[0.163]$} & {$[0.152]$} & {$[0.084]$} \\
\hline \multirow[t]{2}{*}{ Issue year - 1} & $0.519 * * *$ & $0.378 * * *$ & $0.322 * * *$ \\
\hline & {$[0.145]$} & {$[0.124]$} & {$[0.077]$} \\
\hline \multirow[t]{2}{*}{ Issue year } & $0.939 * * *$ & $0.627 * * *$ & $0.622 * * *$ \\
\hline & {$[0.142]$} & {$[0.095]$} & {$[0.095]$} \\
\hline \multirow[t]{2}{*}{ Issue year +1} & $0.999 * * *$ & $0.705 * * *$ & $0.683 * * *$ \\
\hline & {$[0.144]$} & [0.099] & {$[0.103]$} \\
\hline \multirow[t]{2}{*}{ Issue year +2} & $1.072 * * *$ & $0.8 * * *$ & $0.756 * * *$ \\
\hline & {$[0.165]$} & {$[0.113]$} & {$[0.121]$} \\
\hline \multirow[t]{2}{*}{ Issue year +3} & $1.116 * * *$ & $0.867 * * *$ & $0.79 * * *$ \\
\hline & {$[0.187]$} & {$[0.130]$} & {$[0.144]$} \\
\hline \multirow[t]{2}{*}{ Constant } & $12.048 * * *$ & $11.915 * * *$ & $6.175 * * *$ \\
\hline & {$[0.044]$} & {$[0.036]$} & {$[0.033]$} \\
\hline Country Fixed Effects & Yes & Yes & Yes \\
\hline Country Fixed Effects x Time Trend & Yes & Yes & Yes \\
\hline No. of Observations & 208,676 & 138,365 & 107,247 \\
\hline \multirow[t]{3}{*}{ R-squared } & 0.25 & 0.18 & 0.08 \\
\hline & Hrowth Regress & & \\
\hline & Total Assets & Sales & $\begin{array}{l}\text { Number of } \\
\text { Employees }\end{array}$ \\
\hline \multirow[t]{2}{*}{ Issue year - 3} & $8.433 * * *$ & $7.351 * * *$ & $6.971 * * *$ \\
\hline & {$[0.903]$} & {$[1.966]$} & {$[0.934]$} \\
\hline \multirow[t]{2}{*}{ Issue year - 2} & $8.002 * * *$ & $8.894 * * *$ & $5.021 * * *$ \\
\hline & {$[1.341]$} & {$[2.388]$} & {$[1.080]$} \\
\hline \multirow[t]{2}{*}{ Issue year - 1} & $8.649 * * *$ & $7.473 * * *$ & $5.748 * * *$ \\
\hline & {$[2.058]$} & [2.282] & {$[1.073]$} \\
\hline \multirow[t]{2}{*}{ Issue year } & $22.677 * * *$ & $11.35 * * *$ & $8.172 * * *$ \\
\hline & {$[3.083]$} & [1.580] & {$[0.868]$} \\
\hline \multirow[t]{2}{*}{ Issue year +1} & $8.193 * * *$ & $8.762 * * *$ & $6.53 * * *$ \\
\hline & [1.617] & {$[0.941]$} & [1.015] \\
\hline \multirow[t]{2}{*}{ Issue year +2} & $4.315 * * *$ & $5.44 * * *$ & $4.582 * * *$ \\
\hline & {$[0.716]$} & [1.244] & {$[0.483]$} \\
\hline \multirow[t]{2}{*}{ Issue year +3} & $4.244 * * *$ & $5.743 * * *$ & $3.446 * * *$ \\
\hline & [1.175] & [1.081] & [1.052] \\
\hline \multirow[t]{2}{*}{ Constant } & $3.375 * * *$ & $5.278 * * *$ & $2.043 * * *$ \\
\hline & {$[0.283]$} & {$[0.358]$} & {$[0.227]$} \\
\hline Country Fixed Effects & Yes & Yes & Yes \\
\hline Country Fixed Effects x Time Trend & Yes & Yes & Yes \\
\hline No. of Observations & 183,463 & 121,803 & 92,721 \\
\hline R-squared & 0.03 & 0.01 & 0.01 \\
\hline
\end{tabular}


TABLE 7. QUANTILE AND MEAN REgRESSIONS

This table reports quantile and mean regressions of total assets as a proxy for firm size on a constant, a dummy variable for 2010, a dummy variable for issuing firms, and an interaction term of these two dummies. The dependent variable pools the data on total assets at two points in time (2003 and 2010) for all firms with data in both years. Issuing firms are those that raised capital through equity (panel A) or bonds (panel B) between 2003 and 2010. Issuers are also split into domestic and foreign (panels C and D, respectively) according to whether they issued in the country of their domicile or not. Firms that issued only in 2011 are excluded from this table. See the main text for more details. Total assets are in logs of thousands of 2011 U.S. dollars. All coefficients are reported in exponential form. Standard errors, shown in brackets, are bootstrapped (using 400 replications) and clustered at the firm-level. *, **, and $* * *$ denote statistical significance at $10 \%, 5 \%$, and $1 \%$, respectively.

\begin{tabular}{|c|c|c|c|c|c|c|}
\hline \multicolumn{7}{|c|}{ A. Equity Issuers } \\
\hline & \multicolumn{5}{|c|}{ Quantile Regressions } & \multirow{2}{*}{$\begin{array}{c}\text { Mean } \\
\text { Regression }\end{array}$} \\
\hline & 1st Decile & 3rd Decile & 5th Decile & 7th Decile & 9th Decile & \\
\hline Constant & $3,517 * * *$ & 15,067 *** & $64,710 * * *$ & $207,537 * * *$ & $893,746 * * *$ & $55,443 * * *$ \\
\hline (Size of Non-issuers in 2003) & [51.629] & [439] & {$[1,502]$} & {$[4,458]$} & {$[23,565]$} & {$[1,083]$} \\
\hline Issuer Dummy & $1.169 * *$ & $2.048 * * *$ & $2.046 * * *$ & $2.696 * * *$ & $5.597 * * *$ & $2.390 * * *$ \\
\hline (Relative Size of Issuers vs. Non-issuers in 2003) & {$[0.077]$} & {$[0.100]$} & {$[0.083]$} & [0.136] & {$[0.338]$} & [0.092] \\
\hline 2010 Dummy & $1.118 * * *$ & $1.253 * * *$ & $1.362 * * *$ & $1.398 * * *$ & $1.543 * * *$ & $1.340 * * *$ \\
\hline (Relative Size of Non-issuers in 2010 vs. 2003) & {$[0.023]$} & {$[0.058]$} & {$[0.045]$} & [0.046] & {$[0.063]$} & [0.013] \\
\hline Issuer Dummy x 2010 Dummy & $2.313 * * *$ & $1.974 * * *$ & $1.729 * * *$ & $1.595 * * *$ & $1.239 * *$ & $1.746 * * *$ \\
\hline (Relative Growth of Issuers vs. Non-issuers) & [0.182] & [0.149] & {$[0.101]$} & {$[0.104]$} & {$[0.103]$} & [0.033] \\
\hline Average Growth of Non-issuers & $1.6 \%$ & $3.3 \%$ & $4.5 \%$ & $4.9 \%$ & $6.4 \%$ & $4.3 \%$ \\
\hline Average Growth of Issuers & $14.5 \%$ & $13.8 \%$ & $13.0 \%$ & $12.1 \%$ & $9.7 \%$ & $12.9 \%$ \\
\hline $\begin{array}{l}\text { No. of Observations } \\
\text { R-squared }\end{array}$ & 44,302 & 44,302 & 44,302 & 44,302 & 44,302 & $\begin{array}{r}44,302 \\
0.05 \\
\end{array}$ \\
\hline \multicolumn{7}{|c|}{ B. Bond Issuers } \\
\hline & \multicolumn{5}{|c|}{ Quantile Regressions } & Mean \\
\hline & 1st Decile & 3rd Decile & 5th Decile & 7th Decile & 9th Decile & Regression \\
\hline Constant & $3,517 * * *$ & $15,067 * * *$ & $64,710^{* * *}$ & $207,537 * * *$ & $893,746 * * *$ & $55,443 * * *$ \\
\hline (Size of Non-issuers in 2003) & {$[48]$} & {$[430]$} & {$[1,434]$} & {$[4,355]$} & {$[26,179]$} & {$[1,083]$} \\
\hline Issuer Dummy & $14.914 * * *$ & $31.903 * * *$ & $22.931 * * *$ & $22.989 * * *$ & $28.498 * * *$ & $22.941 * * *$ \\
\hline (Relative Size of Issuers vs. Non-issuers in 2003) & {$[1.874]$} & [1.839] & {$[1.107]$} & {$[1.206]$} & {$[1.923]$} & [1.066] \\
\hline 2010 Dummy & $1.118 * * *$ & $1.253 * * *$ & $1.362 * * *$ & $1.398 * * *$ & $1.543 * * *$ & $1.340 * * *$ \\
\hline (Relative Size of Non-issuers in 2010 vs. 2003) & {$[0.023]$} & [0.059] & {$[0.047]$} & {$[0.049]$} & [0.069] & [0.013] \\
\hline Issuer Dummy x 2010 Dummy & $2.432 * * *$ & $1.736 * * *$ & $1.410 * * *$ & $1.231 * * *$ & 1.006 & $1.457 * * *$ \\
\hline (Relative Growth of Issuers vs. Non-issuers) & {$[0.429]$} & [0.135] & {$[0.090]$} & {$[0.087]$} & {$[0.095]$} & {$[0.029]$} \\
\hline Average Growth of Non-issuers & $1.6 \%$ & $3.3 \%$ & $4.5 \%$ & $4.9 \%$ & $6.4 \%$ & $4.3 \%$ \\
\hline Average Growth of Issuers & $15.4 \%$ & $11.7 \%$ & $9.8 \%$ & $8.1 \%$ & $6.5 \%$ & $10.0 \%$ \\
\hline No. of Observations & 36,666 & 36,666 & 36,666 & 36,666 & 36,666 & 36,666 \\
\hline R-squared & & & & & & 0.24 \\
\hline \multicolumn{7}{|c|}{ C. Domestic Issuers } \\
\hline & \multicolumn{5}{|c|}{ Quantile Regressions } & Mean \\
\hline & 1st Decile & 3rd Decile & 5th Decile & 7th Decile & 9th Decile & Regression \\
\hline Constant & $3,517 * * *$ & $15,067^{* * *}$ & $64,710^{* * *}$ & $207,537 * * *$ & $893,746 * * *$ & $55,443 * * *$ \\
\hline (Size of Non-issuers in 2003) & {$[51]$} & {$[468]$} & {$[1,581]$} & {$[4,702]$} & {$[23,770]$} & {$[1,083]$} \\
\hline Issuer Dummy & $1.322 * * *$ & $2.355 * * *$ & $2.278 * * *$ & $2.862 * * *$ & $4.518 * * *$ & $2.466 * * *$ \\
\hline (Relative Size of Issuers vs. Non-issuers in 2003) & {$[0.080]$} & [0.118] & [0.102] & [0.138] & {$[0.288]$} & [0.092] \\
\hline 2010 Dummy & $1.118 * * *$ & $1.253 * * *$ & $1.362 * * *$ & $1.398 * * *$ & $1.543 * * *$ & $1.340 * * *$ \\
\hline (Relative Size of Non-issuers in 2010 vs. 2003) & {$[0.024]$} & {$[0.065]$} & {$[0.050]$} & [0.049] & {$[0.061]$} & {$[0.013]$} \\
\hline Issuer Dummy x 2010 Dummy & $2.124 * * *$ & $1.836 * * *$ & $1.624^{* * *}$ & $1.402 * * *$ & $1.175 *$ & $1.585 * * *$ \\
\hline (Relative Growth of Issuers vs. Non-issuers) & [0.169] & {$[0.145]$} & {$[0.105]$} & [0.089] & {$[0.103]$} & [0.029] \\
\hline Average Growth of Non-issuers & $1.6 \%$ & $3.3 \%$ & $4.5 \%$ & $4.9 \%$ & $6.4 \%$ & $4.3 \%$ \\
\hline Average Growth of Issuers & $13.2 \%$ & $12.6 \%$ & $12.0 \%$ & $10.1 \%$ & $8.9 \%$ & $11.4 \%$ \\
\hline No. of Observations & 43,820 & 43,820 & 43,820 & 43,820 & 43,820 & 43,820 \\
\hline R-squared & & & & & & 0.05 \\
\hline \multicolumn{7}{|c|}{ D. Foreign Issuers } \\
\hline & \multicolumn{5}{|c|}{ Quantile Regressions } & Mean \\
\hline & 1st Decile & 3rd Decile & 5th Decile & 7th Decile & 9th Decile & Regression \\
\hline Constant & $3,517 * * *$ & $15,067 * * *$ & $64,710^{* * *}$ & $207,537 * * *$ & $893,746 * * *$ & $55,443 * * *$ \\
\hline (Size of Non-issuers in 2003) & {$[50]$} & [416] & {$[1,423]$} & {$[4,491]$} & {$[24,076]$} & {$[1,083]$} \\
\hline Issuer Dummy & $5.095 * * *$ & $26.234 * * *$ & $26.871 * * *$ & $29.454 * * *$ & $47.104 * * *$ & $21.326 * * *$ \\
\hline (Relative Size of Issuers vs. Non-issuers in 2003) & {$[0.832]$} & [2.822] & {$[2.254]$} & [2.379] & [4.821] & {$[1.656]$} \\
\hline 2010 Dummy & $1.118 * * *$ & $1.253 * * *$ & $1.362 * * *$ & $1.398 * * *$ & $1.543 * * *$ & $1.340 * * *$ \\
\hline (Relative Size in 2010 vs. 2003 for Non-issuers) & {$[0.023]$} & {$[0.056]$} & [0.046] & {$[0.050]$} & {$[0.062]$} & [0.013] \\
\hline Issuer Dummy x 2010 Dummy & $3.808 * * *$ & $2.199 * * *$ & $1.452 * * *$ & $1.352 * * *$ & 1.089 & $1.802 * * *$ \\
\hline (Relative Growth of Issuers vs. Non-issuers) & {$[0.838]$} & {$[0.340]$} & {$[0.158]$} & {$[0.140]$} & {$[0.162]$} & {$[0.061]$} \\
\hline Average Growth of Non-issuers & $1.6 \%$ & $3.3 \%$ & $4.5 \%$ & $4.9 \%$ & $6.4 \%$ & $4.3 \%$ \\
\hline Average Growth of Issuers & $23.0 \%$ & $15.6 \%$ & $10.2 \%$ & $9.5 \%$ & $7.7 \%$ & $13.4 \%$ \\
\hline No. of Observations & 32,678 & 32,678 & 32,678 & 32,678 & 32,678 & 32,678 \\
\hline R-squared & & & & & & 0.16 \\
\hline
\end{tabular}




\section{TABle 8. EQUity MARKET FINANCING: QUANTILE AND MEAN REgRESSIONS BY COUNTRY GROUP}

This table reports quantile and mean regressions of total assets as a proxy for firm size on a constant, a dummy variable for 2010, a dummy variable for issuing firms, and an interaction term of these two dummies. The dependent variable pools the data on total assets at two points in time (2003 and 2010) for all firms with data in both years. Issuing firms are those that raised capital in equity markets between 2003 and 2010. Firms that issued only in 2011 are excluded from this table. Non-issuers include firms that did not issue (equity or bonds) in our sample. The table presents separately the results for bank-based developed economies (panel A), market-based developed economies (panel B), and emerging economies (panel C). Total assets are in logs of thousands of 2011 U.S. dollars. All coefficients are reported in exponential form. Standard errors, shown in brackets, are bootstrapped (using 400 replications) and clustered at the firm-level. *, **, and *** denote statistical significance at $10 \%, 5 \%$, and $1 \%$, respectively.

\begin{tabular}{|c|c|c|c|c|c|c|}
\hline \multicolumn{7}{|c|}{ A. Bank-based Developed Economies } \\
\hline & \multicolumn{5}{|c|}{ Quantile Regressions } & \multirow{2}{*}{$\begin{array}{c}\text { Mean } \\
\text { Regression }\end{array}$} \\
\hline & 1st Decile & 3rd Decile & 5th Decile & 7th Decile & 9th Decile & \\
\hline Constant & $3,619 * * *$ & $7,282 * * *$ & $40,357 * * *$ & $203,765 * * *$ & $1,004,107 * * *$ & $48,504 * * *$ \\
\hline (Size of Non-issuers in 2003) & {$[45]$} & {$[221]$} & {$[2,717]$} & {$[8,393]$} & {$[44,838]$} & {$[1,542]$} \\
\hline Issuer Dummy & $5.047 * * *$ & $14.100 * * *$ & $8.054 * * *$ & $5.754 * * *$ & $13.335 * * *$ & $7.976 * * *$ \\
\hline (Relative Size of Issuers vs. Non-issuers in 2003) & {$[0.428]$} & [1.091] & {$[0.751]$} & {$[0.533]$} & [1.719] & {$[0.540]$} \\
\hline 2010 Dummy & $1.077 * * *$ & $1.128 * * *$ & 1.129 & $1.143 * *$ & $1.277 * * *$ & $1.156 * * *$ \\
\hline (Relative Size of Non-issuers in 2010 vs. 2003) & {$[0.018]$} & [0.046] & {$[0.111]$} & {$[0.063]$} & {$[0.095]$} & {$[0.011]$} \\
\hline Issuer Dummy x 2010 Dummy & $1.537 * * *$ & $1.411 * * *$ & $1.334 * *$ & $1.307 * *$ & 1.121 & $1.372 * * *$ \\
\hline (Relative Growth of Issuers vs. Non-issuers) & {$[0.177]$} & {$[0.153]$} & {$[0.176]$} & {$[0.176]$} & {$[0.224]$} & {$[0.032]$} \\
\hline Average Growth of Non-issuers & $1.1 \%$ & $1.7 \%$ & $1.7 \%$ & $1.9 \%$ & $3.6 \%$ & $2.1 \%$ \\
\hline Average Growth of Issuers & $7.5 \%$ & $6.9 \%$ & $6.0 \%$ & $5.9 \%$ & $5.3 \%$ & $6.8 \%$ \\
\hline No. of Observations & 14,378 & 14,378 & 14,378 & 14,378 & 14,378 & 14,378 \\
\hline R-squared & & & & & & 0.14 \\
\hline \multicolumn{7}{|c|}{ B. Market-based Developed Economies } \\
\hline & \multicolumn{5}{|c|}{ Quantile Regressions } & Mean \\
\hline & 1st Decile & 3rd Decile & 5th Decile & 7th Decile & 9th Decile & Regression \\
\hline Constant & $4,412 * * *$ & $37,321 * * *$ & $122,467 * * *$ & $348,494 * * *$ & $1,349,377 * * *$ & $91,047 * * *$ \\
\hline (Size of Non-issuers in 2003) & [497] & {$[1,728]$} & {$[4,380]$} & {$[14,300]$} & {$[62,560]$} & {$[3,544]$} \\
\hline Issuer Dummy & $0.477 * * *$ & $0.446 * * *$ & $0.661 * * *$ & $1.393 * * *$ & $3.183 * * *$ & 0.962 \\
\hline (Relative Size of Issuers vs. Non-issuers in 2003) & {$[0.068]$} & {$[0.034]$} & {$[0.048]$} & {$[0.093]$} & {$[0.287]$} & {$[0.060]$} \\
\hline 2010 Dummy & 1.141 & $1.218 * * *$ & $1.226 * * *$ & $1.364 * * *$ & $1.398 * * *$ & $1.260 * * *$ \\
\hline (Relative Size of Non-issuers in 2010 vs. 2003) & {$[0.172]$} & {$[0.086]$} & {$[0.066]$} & {$[0.080]$} & {$[0.110]$} & {$[0.027]$} \\
\hline Issuer Dummy x 2010 Dummy & $2.245 * * *$ & $2.309 * * *$ & $2.292 * * *$ & $1.675 * * *$ & $1.289 * *$ & $1.940 * * *$ \\
\hline (Relative Growth of Issuers vs. Non-issuers) & {$[0.438]$} & {$[0.265]$} & {$[0.230]$} & {$[0.155]$} & {$[0.164]$} & {$[0.066]$} \\
\hline Average Growth of Non-issuers & $1.9 \%$ & $2.9 \%$ & $3.0 \%$ & $4.5 \%$ & $4.9 \%$ & $3.4 \%$ \\
\hline Average Growth of Issuers & $14.4 \%$ & $15.9 \%$ & $15.9 \%$ & $12.5 \%$ & $8.8 \%$ & $13.6 \%$ \\
\hline No. of Observations & 16,890 & 16,890 & 16,890 & 16,890 & 16,890 & 16,890 \\
\hline R-squared & & & & & & 0.02 \\
\hline \multicolumn{7}{|c|}{ C. Emerging Economies } \\
\hline & \multicolumn{5}{|c|}{ Quantile Regressions } & Mean \\
\hline & 1st Decile & 3rd Decile & 5th Decile & 7th Decile & 9th Decile & Regression \\
\hline Constant & $2,627 * * *$ & $16,560 * * *$ & $47,911 * * *$ & $136,635 * * *$ & $464,069 * * *$ & $41,041 * * *$ \\
\hline (Size of Non-issuers in 2003) & {$[166]$} & {$[587]$} & {$[2,049]$} & {$[4,803]$} & {$[20,727]$} & {$[1,238]$} \\
\hline Issuer Dummy & $3.023 * * *$ & $2.195 * * *$ & $2.175 * * *$ & $2.201 * * *$ & $5.259 * * *$ & $2.83 * * *$ \\
\hline (Relative Size of Issuers vs. Non-issuers in 2003) & [0.293] & {$[0.143]$} & {$[0.155]$} & [0.159] & {$[0.560]$} & {$[0.181]$} \\
\hline 2010 Dummy & $1.352 * * *$ & $1.486 * * *$ & $1.696 * * *$ & $1.719 * * *$ & $2.254 * * *$ & $1.67 * * *$ \\
\hline (Relative Size of Non-issuers in 2010 vs. 2003) & {$[0.140]$} & {$[0.080]$} & {$[0.098]$} & {$[0.079]$} & {$[0.138]$} & {$[0.028]$} \\
\hline Issuer Dummy x 2010 Dummy & $1.761 * * *$ & $1.776 * * *$ & $1.937 * * *$ & $2.402 * * *$ & $1.589 * * *$ & $1.89 * * *$ \\
\hline (Relative Growth of Issuers vs. Non-issuers) & {$[0.266]$} & {$[0.199]$} & {$[0.197]$} & {$[0.263]$} & {$[0.235]$} & {$[0.061]$} \\
\hline Average Growth of Non-issuers & $4.4 \%$ & $5.8 \%$ & $7.8 \%$ & $8.0 \%$ & $12.3 \%$ & $7.6 \%$ \\
\hline Average Growth of Issuers & $13.2 \%$ & $14.9 \%$ & $18.5 \%$ & $22.5 \%$ & $20.0 \%$ & $17.8 \%$ \\
\hline No. of Observations & 13,034 & 13,034 & 13,034 & 13,034 & 13,034 & 13,034 \\
\hline R-squared & & & & & & 0.09 \\
\hline
\end{tabular}


TABLE 9. BOND MARKET FINANCING: QUANTILE AND MEAN REgRESSIONS BY COUNTRY GROUP

This table reports quantile and mean regressions of total assets as a proxy for firm size on a constant, a dummy variable for 2010, a dummy variable for issuing firms, and an interaction term of these two dummies. The dependent variable pools the data on total assets at two points in time (2003 and 2010) for all firms with data in both years. Issuing firms are those that raised capital through bonds markets between 2003 and 2010. Firms that issued only in 2011 are excluded from this table. Non-issuers include firms that did not issue (equity or bonds) in our sample. The table presents separate results for bank-based developed economies (panel A), market-based developed economies (panel B), and emerging economies (panel C). Total assets are in logs of thousands of 2011 U.S. dollars. All coefficients are reported in exponential form. Standard errors, shown in brackets, are bootstrapped (using 400 replications) and clustered at the firm-level. *, **, and *** denote statistical significance at $10 \%, 5 \%$, and $1 \%$, respectively.

\begin{tabular}{|c|c|c|c|c|c|c|}
\hline \multicolumn{7}{|c|}{ A. Bank-based Developed Economies } \\
\hline & \multicolumn{5}{|c|}{ Quantile Regressions } & \multirow{2}{*}{$\begin{array}{c}\text { Mean } \\
\text { Regression }\end{array}$} \\
\hline & 1st Decile & 3rd Decile & 5th Decile & 7th Decile & 9th Decile & \\
\hline Constant & $3,619 * * *$ & $7,282 * * *$ & $40,357 * * *$ & $203,765 * * *$ & $1,004,107 * * *$ & $48,504 * * *$ \\
\hline (Size of Non-issuers in 2003) & [44] & {$[225]$} & {$[2,686]$} & {$[8,397]$} & {$[43,122]$} & {$[1,542]$} \\
\hline Issuer Dummy & $43.598 * * *$ & $138.941 * * *$ & $74.131 * * *$ & $47.308 * * *$ & $46.558 * * *$ & $59.753 * * *$ \\
\hline (Relative Size of Issuers vs. Non-issuers in 2003) & {$[5.424]$} & [13.091] & {$[7.770]$} & [5.944] & {$[5.784]$} & {$[4.810]$} \\
\hline 2010 Dummy & $1.077 * * *$ & $1.128 * * *$ & 1.129 & $1.143 * *$ & $1.277 * * *$ & $1.156 * * *$ \\
\hline (Relative Size of Non-issuers in 2010 vs. 2003) & {$[0.018]$} & {$[0.050]$} & {$[0.120]$} & {$[0.066]$} & {$[0.094]$} & {$[0.011]$} \\
\hline Issuer Dummy x 2010 Dummy & 1.098 & 1.092 & 1.227 & 1.308 & 1.097 & $1.183 * * *$ \\
\hline (Relative Growth of Issuers vs. Non-issuers) & {$[0.232]$} & {$[0.136]$} & [0.193] & {$[0.222]$} & {$[0.211]$} & {$[0.026]$} \\
\hline Average Growth of Non-issuers & $1.1 \%$ & $1.7 \%$ & $1.7 \%$ & $1.9 \%$ & $3.6 \%$ & $2.1 \%$ \\
\hline Average Growth of Issuers & $2.4 \%$ & $3.0 \%$ & $4.8 \%$ & $5.9 \%$ & $4.9 \%$ & $4.6 \%$ \\
\hline No. of Observations & 12,686 & 12,686 & 12,686 & 12,686 & 12,686 & 12,686 \\
\hline R-squared & & & & & & 0.29 \\
\hline \multicolumn{7}{|c|}{ B. Market-based Developed Economies } \\
\hline & \multicolumn{5}{|c|}{ Quantile Regressions } & Mean \\
\hline & 1st Decile & 3rd Decile & 5th Decile & 7th Decile & 9th Decile & Regression \\
\hline Constant & $4,412 * * *$ & $37,321 * * *$ & $122,467 * * *$ & $348,494 * * *$ & $1,349,377 * * *$ & $91,047 * * *$ \\
\hline (Size of Non-issuers in 2003) & {$[485]$} & {$[1,629]$} & {$[4,429]$} & {$[14,027]$} & {$[58,020]$} & {$[3,544]$} \\
\hline Issuer Dummy & $4.016 * * *$ & $14.460 * * *$ & $13.498 * * *$ & $13.645 * * *$ & $18.814 * * *$ & $12.010 * * *$ \\
\hline (Relative Size of Issuers vs. Non-issuers in 2003) & {$[0.896]$} & {$[1.485]$} & [1.022] & {$[0.996]$} & [1.832] & {$[0.900]$} \\
\hline 2010 Dummy & 1.141 & $1.218 * * *$ & $1.226 * * *$ & $1.364 * * *$ & $1.398 * * *$ & $1.260 * * *$ \\
\hline (Relative Size of Non-issuers in 2010 vs. 2003) & {$[0.166]$} & {$[0.087]$} & [0.069] & {$[0.083]$} & {$[0.102]$} & {$[0.027]$} \\
\hline Issuer Dummy x 2010 Dummy & $2.636 * * *$ & $1.509 * * *$ & $1.358 * * *$ & 1.171 & 0.976 & $1.470 * * *$ \\
\hline (Relative Growth of Issuers vs. Non-issuers) & {$[0.844]$} & {$[0.202]$} & {$[0.131]$} & {$[0.121]$} & {$[0.123]$} & {$[0.051]$} \\
\hline Average Growth of Non-issuers & $1.9 \%$ & $2.9 \%$ & $3.0 \%$ & $4.5 \%$ & $4.9 \%$ & $3.4 \%$ \\
\hline Average Growth of Issuers & $17.0 \%$ & $9.1 \%$ & $7.6 \%$ & $6.9 \%$ & $4.5 \%$ & $9.2 \%$ \\
\hline No. of Observations & 12,764 & 12,764 & 12,764 & 12,764 & 12,764 & 12,764 \\
\hline R-squared & & & & & & 0.18 \\
\hline \multicolumn{7}{|c|}{ C. Emerging Economies } \\
\hline & \multicolumn{5}{|c|}{ Quantile Regressions } & Mean \\
\hline & 1st Decile & 3rd Decile & 5th Decile & 7th Decile & 9th Decile & Regression \\
\hline Constant & $2,627 * * *$ & $16,560 * * *$ & $47,911 * * *$ & $136,635 * * *$ & $4464,069 * * *$ & $41,041 * * *$ \\
\hline (Size of Non-issuers in 2003) & [152] & {$[618]$} & {$[2,035]$} & {$[4,660]$} & {$[20,065]$} & {$[1,238]$} \\
\hline Issuer Dummy & $29.856 * * *$ & $16.023 * * *$ & $13.952 * * *$ & $12.442 * * *$ & $17.063 * * *$ & $17.430 * * *$ \\
\hline (Relative Size of Issuers vs. Non-issuers in 2003) & [3.836] & [1.198] & {$[1.458]$} & {$[1.311]$} & {$[2.234]$} & {$[1.276]$} \\
\hline 2010 Dummy & $1.352 * * *$ & $1.486 * * *$ & $1.696 * * *$ & $1.719 * * *$ & $2.254 * * *$ & $1.673 * * *$ \\
\hline (Relative Size of Non-issuers in 2010 vs. 2003) & {$[0.135]$} & {$[0.084]$} & {$[0.092]$} & {$[0.081]$} & {$[0.136]$} & {$[0.028]$} \\
\hline Issuer Dummy x 2010 Dummy & $2.467 * * *$ & $2.359 * * *$ & $1.984 * * *$ & $1.997 * * *$ & $1.374 *$ & $1.997 * * *$ \\
\hline (Relative Growth of Issuers vs. Non-issuers) & {$[0.540]$} & {$[0.263]$} & {$[0.276]$} & {$[0.297]$} & {$[0.261]$} & {$[0.072]$} \\
\hline Average Growth of Non-issuers & $4.4 \%$ & $5.8 \%$ & $7.8 \%$ & $8.0 \%$ & $12.3 \%$ & $7.6 \%$ \\
\hline Average Growth of Issuers & $18.8 \%$ & $19.6 \%$ & $18.9 \%$ & $19.3 \%$ & $17.5 \%$ & $18.8 \%$ \\
\hline No. of Observations & 11,216 & 11,216 & 11,216 & 11,216 & 11,216 & 11,216 \\
\hline R-squared & & & & & & 0.24 \\
\hline
\end{tabular}




\section{TABLE 10. MEAN REgRESSIONS CONTROLLING FOR FIRM AGE}

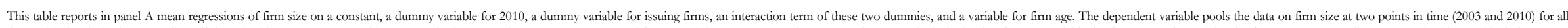

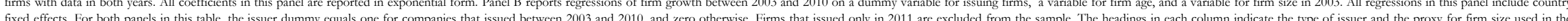
regression estimates. Total assets and sales are in logs of thousands of 2011 U.S. dollars; number of employees is in logs. Robust standard errors, shown in brackets, are clustered at firm level. *, **, and *** denote statistical significance at $10 \%$, $5 \%$, and $1 \%$, respectively.

\begin{tabular}{|c|c|c|c|c|c|c|c|c|c|}
\hline \multicolumn{10}{|c|}{ A. Regressions in Levels } \\
\hline & \multicolumn{3}{|c|}{ Whole Sample } & \multicolumn{2}{|c|}{ Bank-based Developed Economies } & \multicolumn{2}{|c|}{ Market-based Developed Economies } & \multicolumn{2}{|c|}{ Emerging Economies } \\
\hline & All Issuers & All Issuers & All Issuers & Equity Issuers & Bond Issuers & Equity Issuers & Bond Issuers & Equity Issuers & Bond Issuers \\
\hline Proxy for Firm Size & Total Assets & Sales & Number of Employees & Total Assets & Total Assets & Total Assets & Total Assets & Total Assets & Total Assets \\
\hline Constant & $18,650 * * *$ & $24,736 * * *$ & $207 * * *$ & $13,062 * * *$ & $13,732 * * *$ & $27,150 * * *$ & $33,395 * * *$ & $31,309 * * *$ & $34,955 * * *$ \\
\hline (Size of Non-issuers in 2003) & [556] & {$[1,037]$} & {$[7]$} & [740] & {$[838]$} & {$[1,609]$} & {$[1,951]$} & {$[1,568]$} & {$[1,681]$} \\
\hline Issuer Dummy & $3.642 * * *$ & $2.396 * * *$ & $2.027 * * *$ & $5.165 * * *$ & $23.018 * * *$ & $1.267 * * *$ & $11.964 * * *$ & $2.792 * * *$ & $15.905 * * *$ \\
\hline (Relative Size of Issuers vs. Non-issuers in 2003) & {$[0.124]$} & {$[0.093]$} & {$[0.081]$} & {$[0.340]$} & [2.192] & {$[0.078]$} & [0.883] & {$[0.177]$} & {$[1.146]$} \\
\hline 2010 Dummy & $1.328 * * *$ & $1.424 * * *$ & $1.024 *$ & $1.151 * * *$ & $1.151 * * *$ & $1.231 * * *$ & $1.231 * * *$ & $1.668 * * *$ & $1.668 * * *$ \\
\hline (Relative Size of Non-issuers in 2010 vs. 2003) & {$[0.013]$} & {$[0.021]$} & {$[0.013]$} & {$[0.011]$} & {$[0.011]$} & {$[0.028]$} & {$[0.028]$} & {$[0.028]$} & {$[0.028]$} \\
\hline Issuer Dummy x 2010 Dummy & $1.638 * * *$ & $1.467 * * *$ & $1.413 * * *$ & $1.376 * * *$ & $1.185 * * *$ & $2.001 * * *$ & $1.497 * * *$ & $1.887 * * *$ & $2.023 * * *$ \\
\hline (Relative Growth of Issuers vs. Non-issuers) & {$[0.028]$} & {$[0.032]$} & {$[0.026]$} & {$[0.033]$} & {$[0.026]$} & {$[0.070]$} & {$[0.054]$} & {$[0.061]$} & {$[0.072]$} \\
\hline \multirow[t]{2}{*}{ Firm Age (in 2011) } & $1.029 * * *$ & $1.024 * * *$ & $1.015 * * *$ & $1.034 * * *$ & $1.033 * * *$ & $1.028 * * *$ & $1.023 * * *$ & $1.009 * * *$ & $1.006 * * *$ \\
\hline & {$[0.001]$} & {$[0.001]$} & {$[0.001]$} & {$[0.002]$} & {$[0.002]$} & {$[0.001]$} & {$[0.001]$} & {$[0.001]$} & [0.001] \\
\hline No. of Observations & 46,048 & 30,634 & 23,944 & 14,156 & 12,508 & 15,892 & 11,938 & 12,794 & 10,976 \\
\hline R-squared & 0.22 & 0.15 & 0.10 & 0.39 & 0.50 & 0.12 & 0.27 & 0.10 & 0.24 \\
\hline \multicolumn{10}{|c|}{ B. Growth Regressions } \\
\hline & \multicolumn{3}{|c|}{ Whole Sample } & \multicolumn{2}{|c|}{ Bank-based Developed Economies } & \multicolumn{2}{|c|}{ Market-based Developed Economies } & \multicolumn{2}{|c|}{ Emerging Economies } \\
\hline & All Issuers & All Issuers & All Issuers & Equity Issuers & Bond Issuers & Equity Issuers & Bond Issuers & Equity Issuers & Bond Issuers \\
\hline Proxy for Firm Growth & Total Assets & Sales & Number of Employees & Total Assets & Total Assets & Total Assets & Total Assets & Total Assets & Total Assets \\
\hline Issuer Dummy & 0.637 *** & 0.569 *** & $0.368 * * *$ & $\begin{array}{rl}0.350 & * * * \\
0\end{array}$ & $0.319 * * *$ & $0.712 * * *$ & $0.772 * * *$ & $0.786 * * *$ & $1.021 * * *$ \\
\hline Firm Age (in 2011) & $\begin{array}{l}{[0.019]} \\
0.000 *\end{array}$ & $\begin{array}{r}0.022] \\
0.000\end{array}$ & $\begin{array}{l}{[0.019]} \\
-0.001 * * *\end{array}$ & 0.000 & $\begin{array}{r}0.051] \\
0.000\end{array}$ & $0.001 * *$ & $\begin{array}{r}{[.0 .000]} \\
0.000\end{array}$ & $\begin{array}{r}0.034] \\
0.001\end{array}$ & 0.001 \\
\hline & {$[0.000]$} & {$[0.000]$} & {$[0.000]$} & {$[0.000]$} & {$[0.000]$} & {$[0.000]$} & {$[0.000]$} & {$[0.001]$} & {$[0.001]$} \\
\hline Total Assets in 2003 & $\begin{array}{l}-0.135 \text { *** } \\
{[0.007]}\end{array}$ & & & $\begin{array}{ll}-0.064 & * * * \\
{[0.008]} & \end{array}$ & $\begin{array}{l}-0.051 * * * \\
{[0.009]}\end{array}$ & $\begin{array}{l}-0.179 * * * \\
{[0.011]}\end{array}$ & $\begin{array}{l}-0.142 * * * \\
{[0.013]}\end{array}$ & $\begin{array}{l}-0.105 * * * \\
{[0.018]}\end{array}$ & $\begin{array}{l}-0.109 * * * \\
{[0.022]}\end{array}$ \\
\hline Total Sales in 2003 & & $\begin{array}{l}-0.171 \text { *** } \\
{[0.009]}\end{array}$ & & & & & & & \\
\hline Total Number of Employees in 2003 & & & $\begin{array}{l}-0.102 * * * \\
{[0.006]}\end{array}$ & & & & & & \\
\hline Country Fixed Effects & Yes & Yes & Yes & Yes & Yes & Yes & Yes & Yes & Yes \\
\hline No. of Observations & 23,024 & 15,317 & 11,972 & 7,078 & 6,254 & 7,946 & 5,969 & 6,397 & 5,488 \\
\hline R-squared & 0.15 & 0.15 & 0.10 & 0.11 & 0.09 & 0.16 & 0.11 & 0.12 & 0.12 \\
\hline
\end{tabular}


TABLE 11. QUANTILE AND MEAN REgRESSIONS CONTROLLING FOR FIRM AGE

This table reports quantile and mean regressions for total assets as a proxy for firm size on a constant, a dummy variable for 2010 , a dummy variable for issuing firms, and an interaction term of these two dummies. The dependent variable pools the data on firm size at two points in time (2003 and 2010) for all firms with data in both years. Issuing firms are those that raised capital through equity or bonds between 2003 and 2010. Firms that issued only in 2011 are excluded from this table. The sample of firms vary in the difterent panels: panel A comprises young firms in

\section{Constant}

(Size of Non-issuers in 2003 for Young Firms)

Issuer Dummy

(Relative Size of Issuers vs. Non-issuers in 2003 for Young Firms

(Relative Size of Non-issuers in 2003 vs. 2010 for Young Firms.

Issuer Dummy x 2010 Dummy

(Relative Growth of Issuers vs. Non-issuers for Young Firms)

Average Growth of Young Non-issuers

Average Growth of Young Issuers

A. Young firms

No. of Observations

\begin{tabular}{|c|c|c|c|c|c|c|c|c|c|}
\hline \multicolumn{9}{|c|}{ Quantile Regressions } & \multirow{2}{*}{$\begin{array}{c}\text { Mean } \\
\text { Regression } \\
\end{array}$} \\
\hline 1st Decile & 2nd Decile & 3rd Decile & 4th Decile & 5th Decile & 6th Decile & 7th Decile & 8th Decile & 9th Decile & \\
\hline $3,236 * * *$ & $3,736^{* * *}$ & $3,900 * * *$ & $4,363 * * *$ & $5,166 * * *$ & $6,646 * * *$ & $9,633 * * *$ & $21,130^{* * *}$ & $72,192 * * *$ & 8,267 *** \\
\hline [97] & [33] & [31] & & [153] & [330] & [449] & {$[2,268]$} & {$[18,793]$} & [498] \\
\hline $0.298 * * *$ & $1.433 * *$ & $3.556 * * *$ & $6.586^{* * *}$ & $10.960 * * *$ & $21.268 * * *$ & $42.916 * * *$ & $69.117 * * *$ & $83.320 * * *$ & $8.855 * * *$ \\
\hline$[0.090]$ & [0.244] & [0.532] & {$[0.763]$} & {$[1.590]$} & {$[3.610]$} & [11.663] & [15.995] & [27.500] & [1.296] \\
\hline $1.060 *$ & $1.066 * * *$ & $1.153 * * *$ & $1.213 * * *$ & $1.288 * * *$ & $1.306 * * *$ & $1.392 * * *$ & 1.357 * & $2.928 * * *$ & $1.428 * * *$ \\
\hline$[0.034]$ & {$[0.016]$} & {$[0.021]$} & {$[0.043]$} & {$[0.071]$} & {$[0.085]$} & {$[0.124]$} & {$[0.228]$} & [1.083] & {$[0.056]$} \\
\hline $8.280 * * *$ & $3.956 * * *$ & $3.438 * * *$ & $3.573 * * *$ & $3.724 * * *$ & $3.362 * * *$ & $2.458 * * *$ & $2.061 * *$ & 0.644 & 2.748 *** \\
\hline [3.029] & {$[0.990]$} & {$[0.761]$} & {$[0.709]$} & {$[0.837]$} & {$[0.830]$} & {$[0.790]$} & {$[0.649]$} & {$[0.300]$} & {$[0.226]$} \\
\hline $0.8 \%$ & $0.9 \%$ & $2.1 \%$ & $2.8 \%$ & $3.7 \%$ & $3.9 \%$ & $4.8 \%$ & $4.5 \%$ & $16.6 \%$ & $5.2 \%$ \\
\hline $36.4 \%$ & $22.8 \%$ & $21.7 \%$ & $23.3 \%$ & $25.1 \%$ & $23.5 \%$ & $19.2 \%$ & $15.8 \%$ & $9.5 \%$ & $21.6 \%$ \\
\hline 3,654 & 3,654 & 3,654 & 3,654 & 3,654 & 3,654 & 3,654 & 3,654 & 3,654 & 3,654 \\
\hline
\end{tabular}

R-squared

\begin{tabular}{ll} 
B. Mature Firms & \\
\hline & Quantile Regressions
\end{tabular}

Constant

(Size of Non-issuers in 2003 for Mature Firms)

Issuer Dummy

(Relative Size of Issuers vs. Non-issuers in 2003 for Mature Firms) 2010 Dummy

(Relative Size of Non-issuers in 2003 vs. 2010 for Mature Firms)

Issuer Dummy x 2010 Dummy

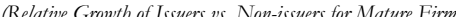

Average Growth of Mature Non-issuers

Average Growth of Mature Issuers

\begin{tabular}{|c|c|c|c|c|c|c|c|c|c|}
\hline & & & & & & & & & \\
\hline & & & 4th & 5 th & 6th & & & 9 th $\mathrm{Dc}_{\mathrm{c}}$ & ssion \\
\hline & & $137 * * *$ & 15,812 **** & 31,008 *** & 60,291 *** & $111,899 * * *$ & $208,103 * * *$ & $466,172 * * *$ & 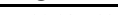 \\
\hline
\end{tabular}

$[71] \quad[132]$

$0.077]$

$1.208 * * * \quad 1.156 * *$

$[0.047] \quad[0.048]$

1.955 *** $\quad 2.223$

$[238]$

$[591]$
$2.522 * * *$

$[0.150]$

1.215 ***

[0.060]

[0.143]

1.297 ***

[0.086] $[1,089]$

$2.432 * * *$

[0.141]

$1.350 * * *$

$2.084 * * *$

2.029 ***

$[0.070]$

[0.189]

$[2,198]$

2.548 ***

$[0.156]$ ***

$[0.073]$

2.026 ***

$[0.185]$

$2.7 \% \quad 2.1 \%$

$2.8 \%-3.8 \%$

$4.4 \%$

$\begin{array}{rr}3.8 \% & 4.4 \% \\ 14.8 \% & 16.5 \%\end{array}$

23,186

23,186

23,186

23,186

23,186

$4.4 \%$

$4.4 \%$
$15.5 \%$

23,186

$[3,644]$
$2.919 * * *$

[0.183]

1.433 ***

1.433
$1.927 * * *$

[0.178]

$5.3 \%$

$5.3 \%$
$15.6 \%$

23,186

$[5,298]$

$3.829 * *$

$[0.267]$
1.597 ***

$[0.084]$

$[0.084]$
$1.542 * *$

[0.156]

[16,351]

$5.394 * *$

[0.340]

$1.774 * * *$

[0.093]

$1.301 *$

$[0.126]$

$6.9 \%$
$13.7 \%$

$8.5 \%$
$12.7 \%$

23,186

23,186

[812]

R-squared

C. Old Firms

\begin{tabular}{|c|c|c|c|}
\hline 1st Decile & 2nd Decile & 3rd Decile & 4th D \\
\hline $12,862 * * *$ & $31,763 * * *$ & 62,796 **** & 103 \\
\hline [690] & {$[1,200]$} & {$[1,839]$} & {$[3$,} \\
\hline $2.781 * * *$ & 3.559 *** & $3.789 * * *$ & \\
\hline$[0.268]$ & {$[0.238]$} & [0.232] & \\
\hline $\begin{array}{l}1.251 * * * \\
{[0.102]}\end{array}$ & $\begin{array}{l}1.302 * * * \\
{[0.074]}\end{array}$ & $\begin{array}{l}1.287 \text { *** } \\
{[0.056]}\end{array}$ & \\
\hline $\begin{array}{c}1.323 * * \\
{[0.170]}\end{array}$ & $\begin{array}{l}1.223 \text { ** } \\
{[0.108]}\end{array}$ & $\begin{array}{l}1.248 * * * \\
{[0.103]}\end{array}$ & 1.3 \\
\hline $3.3 \%$ & $3.8 \%$ & $3.7 \%$ & 3.2 \\
\hline $7.5 \%$ & $6.9 \%$ & $7.0 \%$ & 7. \\
\hline 19,20 & 19,208 & 19,208 & \\
\hline
\end{tabular}

Quantile Regressions

Constant

(Size of Non-issuers in 2003 for Old Firms)

Issuer Dummy

(Relative Size of Issuers vs. Non-issuers in 2003 for Old Firms) 2010 Dummy

Din 2003 vs. 2010 for Old Firms)

Issuer Dummy x 2010 Dummy

(Relative Growth of Issuers vs. Non-issuers for Old Firm.s

Average Growth of Old Non-issuers

Average Growth of Old Issuers

19,208

19,208

19,208

19,208

5th Decile

$\frac{6 \text { th Decile }}{261,645 * * *}$

$[4,646]$

$4.995 * * *$

[0.302]

1.259
$[0.051]$

$1.203 * *$
$[0.092]$

$[7,477]$

406,848 ****
$[11,471]$

[0.337]

$1.232 * *$

$[0.048]$
1.263 $* * *$

[0.099]

$7.109 * * *$

[0.435]

1.278 **

$10.050]$
$1.195 * *$

1.195 **
$[0.098]$

$3.3 \%$

$3.0 \%$

$3.6 \%$

$6.2 \%$

19,208

19,208

19,208

19,208

8th Decile

$[18,750]$
$9.063 * * *$

[0.636]

1.320
$[0.050]$

$[0.050]$
1.184 *

$1.184 *$
$[0.103]$

$4.0 \%$

$4.0 \%$
$6.6 \%$

9th Decile

$1,552,118 *$

$[73,079]$
11.908 ***

[0.899]

$1.390 * * *$

$[0.085]$

1.085
$[0.118$

$[0.132]$

1.375 ***

$[0.020]$

$[0.049]$

$4.7 \%$

R-squared

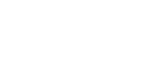

\begin{tabular}{rr}
19,208 \\
19,208 & 0.14 \\
\hline
\end{tabular}




\section{Appendix Table 1. Country Coverage}

This table reports the number of issuing and non-issuing firms per country. The table also reports the classification of countries according to their level of development (panels A, B, and C). Issuing firms are those with at least one equity or bond issuance between 2003 and 2011. Non-issuing firms are all other firms in the sample.

A. Developed Bank-based Economies

\begin{tabular}{lcc}
\multicolumn{3}{c}{ A. Developed Bank-based Economies } \\
\cline { 2 - 3 } \multicolumn{1}{c}{ Country } & \multicolumn{2}{c}{ Number of Firms } \\
\cline { 2 - 3 } \cline { 3 - 3 } \cline { 3 - 3 } Austria & Non-issuing Firms & Issuing Firms \\
\cline { 2 - 3 } Belgium & 133 & 54 \\
Cyprus & 129 & 98 \\
Denmark & 146 & 23 \\
Germany & 723 & 85 \\
Ireland & 46 & 410 \\
Israel & 535 & 55 \\
Italy & 156 & 93 \\
Japan & 1,978 & 183 \\
Netherlands & 147 & 2,125 \\
New Zealand & 55 & 109 \\
Norway & 239 & 105 \\
Poland & 504 & 148 \\
Portugal & 67 & 335 \\
Spain & 3,028 & 34 \\
United Arab Emirates & 73 & 91 \\
\hline & & 37 \\
\hline
\end{tabular}

B. Developed Market-based Economies

\begin{tabular}{lccc}
\hline & \multicolumn{2}{c}{ Number of Firms } \\
Australia & Non-issuing Firms & Issuing Firms \\
\cline { 3 - 3 } Greece & 296 & 1,636 \\
Finland & 83 & 56 \\
France & 680 & 71 \\
Hong Kong SAR, China & 78 & 461 \\
Kuwait & 181 & 160 \\
Luxembourg & 44 & 32 \\
Oman & 110 & 32 \\
Qatar & 27 & 24 \\
Saudi Arabia & 73 & 18 \\
Singapore & 225 & 71 \\
Sweden & 423 & 491 \\
Switzerland & 186 & 281 \\
United Kingdom & 1,540 & 142 \\
United States & 4,622 & 1,452 \\
\hline
\end{tabular}

C. Emerging Economies

\begin{tabular}{|c|c|c|}
\hline \multirow[b]{2}{*}{ Country } & \multicolumn{2}{|c|}{ Number of Firms } \\
\hline & Non-issuing Firms & Issuing Firms \\
\hline Argentina & 71 & 37 \\
\hline Brazil & 297 & 250 \\
\hline Bulgaria & 402 & 26 \\
\hline Chile & 172 & 82 \\
\hline China & 1,268 & 1,471 \\
\hline Colombia & 94 & 26 \\
\hline India & 3,501 & 1,233 \\
\hline Indonesia & 230 & 222 \\
\hline Jordan & 202 & 57 \\
\hline Malaysia & 472 & 596 \\
\hline Mexico & 81 & 75 \\
\hline Pakistan & 525 & 42 \\
\hline Peru & 142 & 47 \\
\hline Philippines & 145 & 111 \\
\hline Russian Federation & 1,161 & 117 \\
\hline South Africa & 285 & 96 \\
\hline Sri Lanka & 187 & 64 \\
\hline Thailand & 260 & 320 \\
\hline Turkey & 268 & 120 \\
\hline Vietnam & 565 & 247 \\
\hline
\end{tabular}




\section{APPENdix Figure 1. Percentage OF Issuing Firms}

This figure shows the number of issuing firms as a percentage of the number of firms in each country in the sample. Issuing firms are those with at least one equity or bond issuance between 2003 and 2011.

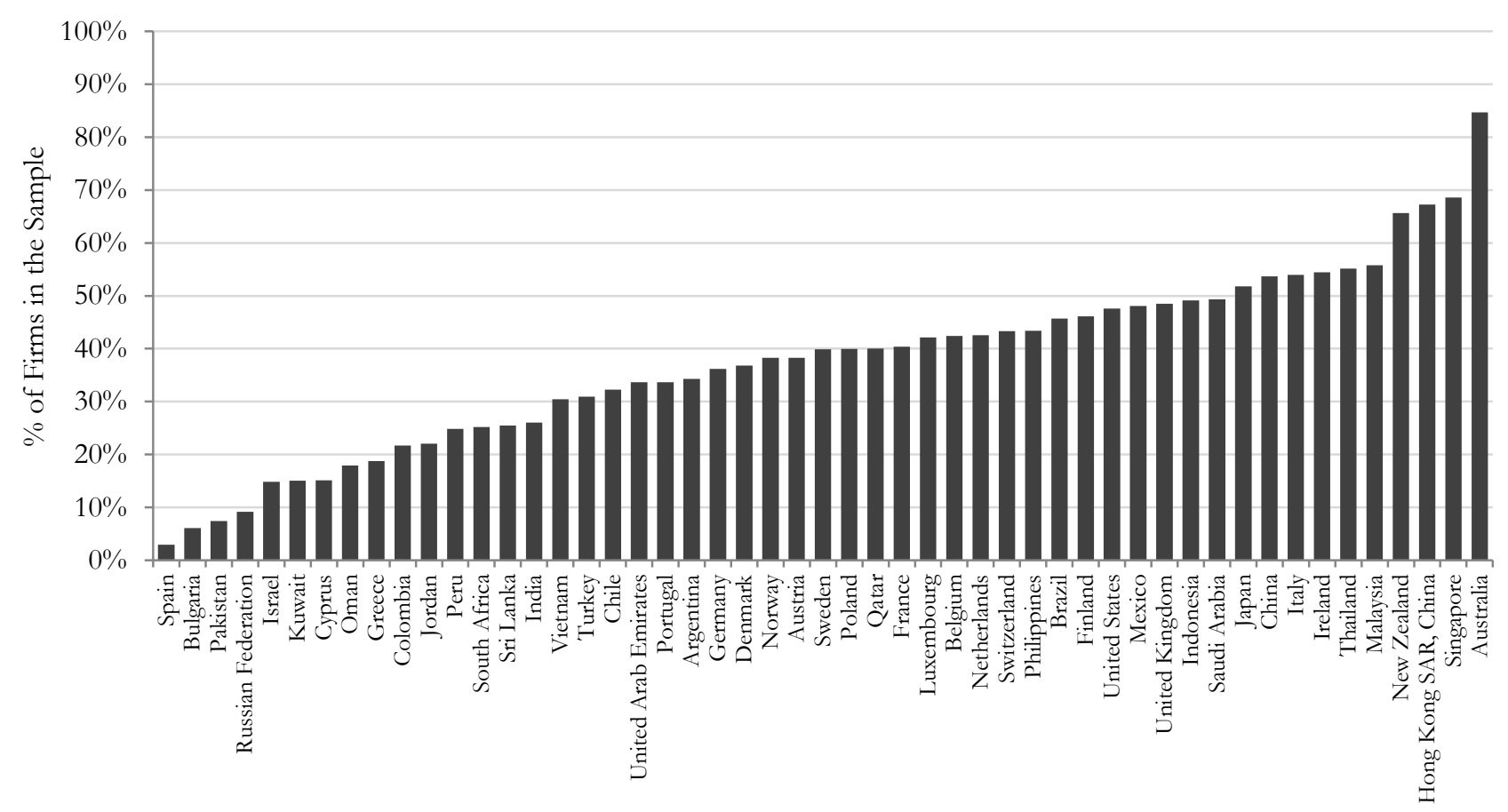

